\title{
A MAGYAR FőÚRI PALOTÁK ÉS EURÓPAI ELŐKÉPEIK DISZPOZÍCIÓJA A 18-19. SZÁZADI VÁROSI KÖRNYEZETBEN
}

\author{
FEKETE J. CSABA \\ PhD, okl. építészmérnök, müemlékvédelmi egyetemi szakmérnök, \\ müemléki szakértő, egyetemi adjunktus. \\ BME Építészettörténeti és Múemléki Tanszék. \\ 1111 Budapest, Múegyetem rkp. 3. K. 282. \\ Tel.: (+36-1) 463-1330. E-mail: fekete@eptort.bme.hu
}

\begin{abstract}
A fő́ri palota mint sajátos épületfajta rendeltetéséből következően azon túl, hogy egy-egy család lakóhelyéül szolgált, az arisztokrácia társadalmi helyzetét, rangját is reprezentálta. A palota az ókor óta a legvagyonosabb és uralkodó társadalmi réteg városi lakóhelye, hatalmának, jelenlétének reprezentatív szimbóluma volt. A város társadalmi életének újkori fejlődése az arisztokráciát vidéki birtokairól a sủrübb városi tartózkodásra ösztönözte. A politikai és hatalmi életben való részvétel mellett a városi tartózkodás együtt járt a „szezon” (báli szezon, színházi évad, lóverseny) eseményein való személyes reprezentálással is. Az arisztokrácia városi lakóhelyeinek a településen belüli elhelyezése, rendeltetéselemeinek építészeti diszpozíciója (elrendezése), az építtetők sajátos életmódjával összefüggésben, elsősorban viselkedésszociológiai szempontú megközelítéssel válik igazán értelmezhetővé, mert az elhelyezés és az elrendezés változatai a jellegzetes életforma reprezentatív „építészeti leképezéseként” tűnnek fel a nagyvárosi szövetben. A 18-19. században a foúri életforma változása az arisztokrácia társadalmi osztályában a főnemesség történeti-jogi és viselkedésszociológiai értelemben is vett elválását, rétegképző hatását mutatja. Ez a városi környezetben a palotáknak a városi központ köré centralizálódó, ide csoportosuló, illetve koncentrálódó vagy a városfalakon kívüli, elkülönült térbeli elhelyezkedésében és sajátosan izolált építészeti kialakításában jelent meg hazánkban, valamint a hazai előképül szolgáló - példaként kiemelt - jelentős európai nagyvárosokban is. Pozsony és Pest-Buda esetében a 18-19. században kialakított hatalmi központok - a királyi várpalota és az országgyülés üléstermei voltak a foúri politizálás és hatalomgyakorlás elsődleges helyszínei. A magánpaloták nagy számban ezért ezek köré rendezödtek, ugyanakkor kedvelt volt a városfalakon kívüli, de ahhoz közeli terület is, amely a 17. század végétől alkalmasnak bizonyult tágas kertekkel övezett paloták felépítésére. A palotákhoz kapcsolódó kertek kialakítására a sủrü városi szövetben csak igen korlátozott lehetőség volt, amely alól szinte páratlan kivétel a prágai várhegy déli lejtőit elfoglaló, teraszos kialakítású foúri magánkertek pompás csoportja. A paloták térbeli elrendezésének előzményei már a 13-14. századi itáliai városokban megtalálhatók. A típusalkotó épületek Firenzében jelentek meg a 15. század közepén, a hazánkban mintaadó változataikat a 16-17. században Rómában, a 17-18. században pedig Párizsban és Bécsben érlelték ki.
\end{abstract}

Kulcsszavak: palota, diszpozíció, főúri lakóhely, alaprajzi elrendezés, barokk, historizmus 
A magyarországi főnemesség életmódjának müvelődéstörténeti feldolgozása és tudományos elemzése - beleértve a kiemelt társadalmi pozícióból eredő jellegzetes politikai, kulturális, társasági, családi és magánéletet - a 18-19. század korszakára teljességében még nem készült el. A téma olyan szerteágazó és összetett, hogy jelenleg a korabeli forrásokból vagy a 20. századi szakirodalomból vett tanulmányokban elszórt utalásoknál több alig áll rendelkezésre a főnemesi életformának a rang és a politikai vagy „,foglalkozási presztízs” szerinti viselkedésszociológiai rétegződésének tárgykörében. ${ }^{1}$ A társadalomtörténet, mint a müvelődéstörténet egyik diszciplínája, a magyarországi társadalom fejlődésében a rendek és az osztályok szerinti tagolódás modelljét alkalmazta a 18. és a 19. századi társadalmi rétegek, illetve változások jellemzésére. Az 1848-1849-ig, illetve 1853-ig fennálló nemesi rendi társadalomban az azonos jogállású, örökletesen kiváltságolt, érdekeit politikai síkon is képviselők csoportja alkotta hagyományosan a vezető társadalmi réteget, az arisztokráciát. $^{2}$

A rendiség történeti-jogi értelmezése mellett kialakult a rendek viselkedésszociológiai értelemben vett értelmezése is, amely az egyén státusát rendi helyzete (konvenció, connubium, kommenzalitás) szempontjából írta le. ${ }^{3}$ Ezek a szempontok nemcsak a társadalomtörténetben teszik lehetővé egy társadalmi réteg jellegzetességeinek, változásának, átalakulásának sokkal érzékenyebb megfigyelését, hanem tárgyunk, a foúri építtetői igények összetett rendszere, valamint a térhasználatot is meghatározó életforma felé terelik a figyelmet. Ez a szociológiai megközelítés lehetővé teszi a hazai fơuri magánépítészet olyan sajátosságainak meghatározását, amelyek az európai arisztokrácia magánépítészetének hasonló vonásait mutatja, annak ellenére, hogy a nyugati arisztokrácia társadalmi fejlődése és rétegződése a hazai folyamatoktól több ponton eltért.

Magyarországon az egységes nemesi rend ${ }^{4}$ felső rétegének, a förendiség kialakulásának alapja nem a nyugat-európai feudális jellegű hübéri tartományuraság, hanem az országos tisztségek, illetve a közjogi állással bíró egyházak legmagasabb tisztsé-

\footnotetext{
${ }^{1}$ A főúri életmód általános összefoglaló művei közül, az elemzett korszakot megelőző időszakra 1 . Radvánszky 1879-1896; Koltai 2001; a 18. századra 1. Gosztonyi 1911; G. Györffy 1991; Kosáry 1996; a 19-20. század fordulójára 1. Baji-Csorba 1994.

${ }^{2}$ A nemesség társadalomtörténeti elemzését adja pl. Pálmány 1997. 37-96; Halmos 1995. 445-482; Vörös 1987. 397-405.

${ }^{3}$ Max Weber Gazdaság és társadalom c. munkája nyomán 1. Kövér 2006. 99.

${ }^{4} \mathrm{Az}$ 1351. évi ősiség törvénnyel egységessé tett magyar nemesi rendhez való tartozást kifejező magyar nemes (nobilis Hungarus) jelentőségét a középkori Magyarországon, a „Szent Korona tagjaként” a politikai jogok kizárólagos birtoklása adta. A nemesi rend a sarkalatos nemesi jogok vagy szabadságok tekintetében mindvégig egységes maradt, tehát a magyar rendi jogosultak elvileg egyenértékűek voltak, ami egy zárt körrel és az annak középpontjában álló koronás királlyal volt jellemezhető. Vajay Szabolcs ezt „nemesi demokráciá”-nak nevezi (1. Vajay 1966. 362). A magyar nemesi rend egységességével alapvetően eltért a számos lépcsőfokból álló nyugat-európai, pl. az angol feudális rendiség hierarchikus jellegétől, amelynek gúlája csúcsán az uralkodó állt. Magyarországon a nemesség megszerzésének módja a honfoglaló nemzetségektől való leszármazás (primae occupationis) és a királyi adományozás lehetett. Az utóbbinak három útja: a jószágadományozás (donációs nemesek); a királyi oklevéllel, de birtokadomány nélküli nemesítés (armális nemesek) és az ünnepélyes honosítás (indigenátus) volt. (Bővebben 1. Bölöny 1981. 31-33; ill. Gudenus-Szentirmay 1989. 24-25.)
} 
geinek betöltése volt. A fönemesi rendek kialakulásának folyamata akkor fejeződött be, amikor az örökölhető rendi állást - vagyis a birodalmi gyülésen ülési és szavazati jogot - az uralkodók privilegiális oklevelekben, külön ranggal (gróf, báró) az utódra kiterjedő hatállyal, a 15 . században adományozni kezdték. ${ }^{5}$

A kora újkori nemesi rend kettéválásakor, a történeti-jogi értelemben vett rendiséget megelözte egyfajta származás vagy foglalkozás presztízsén, életvitelbeli, neveltetésbeli különbségeken alapuló tagolódás, tehát viselkedésszociológiai értelemben vett rendiség. A nemesi renden belül a 15. század közepétől a tisztségviselő vagy erre elvben jogigényt formáló országbárók (,,barones naturales”) mellett feltűntek - mintegy elkülönülö, sajátos csoportot alkotva - az országos ügyintézés keretein kívüli, címadományozással kitüntetettek (,, barones solo nomine”) is. Az 1608. évi I. tc. különítette el intézményesen és alkotmányjogi tekintetben is a főnemességet a köznemességtől, és az addig egységes országgyülés alsó- és felsőtáblára oszlott. Ez a fönemesek megkülönböztetett törvényhozói jogállását a felsőtáblán való ülésezés kiváltságával biztosította. Ettől kezdve a személyre szóló törvényhozói jog együtt járt minden fönemesi címadományozással, illetve külföldi címeknek magyarországi honfiúsításával. ${ }^{6} \mathrm{Az}$ 1754-1755. évi uralkodói rendelet után pedig egyértelmüen szabályozottá vált, hogy csak királyi adományozás alapján juthat valaki nemesi címhez, és fönemesi ranghoz - utóbbival megszerezve az örökös felsőtábla-tagsági jogát -, és ez mintegy alulról lezárta a nemesi rend mindkét, köz- és főnemesi rétegét.

A förendiház szervezetét 1885-ben reformálták meg (1885. évi VII. tc.), ${ }^{7}$ így a 19. századi társadalmi átalakulás csak megkésve érintette a fönemesség történeti jogi képviseletét és megkülönböztetett törvényhozói jogállását. A förendiházi reform életbelépése után a förendiházi tagság már nem volt egyenértékủ a főrendi minőséggel. A reform folytán ugyanis a förendiháznak nagy számban váltak új tagjaivá olyanok (a legmagasabb közhivatalnokok, bírói és egyházi fötisztségviselők, továbbá a király által élethossziglan kinevezett 50 tag), akik nem voltak förangúak, de talán még nagyobb számban maradtak ki főnemesek a korábbi tagok sorából. Utóbbit két rendelkezés okozta. Az egyik jelentősen korlátozta az indigéna (honfiúsított) fönemesek részvételét, nemcsak a tárgyaláson bevezetett magyar nyelvvel, hanem azzal is, hogy bármely külföldön is birtokos magyar förend Magyarországon csak akkor tarthatta meg förendiházi tagságát, ha más országokban e jog gyakorlásáról lemondott. ${ }^{8} \mathrm{~A}$ másik rendelkezés szerint csak bizonyos jövedelemszint fölötti főnemes lehetett auto-

\footnotetext{
${ }^{5}$ A főnemesi rang hazánkban csak a mohácsi vész után terjedt el, s közjogi különállása csak a főrendi táblai személyes jelenlét jogában nyilvánult meg. A legrégebbi főnemesi címmel a Csáky, a Forgách, az Erdődy, a Nádasdy, a Pálffy, a Perényi, a Révay család bírt. A 17. század elején kapott fónemesi címet a Batthyány, az Esterházy, a Cziráky-Draskovich, a Károlyi, a Keglevich, a Kornis, a Nyáry, a Pongrácz, a Serényi és a Zichy család. Az Andrássy, az Apponyi, a Bethlen, az Orssich, a Szapáry, a Széchényi, a Teleki család főnemessége az 1660-as évek végéről származott. (Gudenus-Szentirmay 1989. 15.)

${ }^{6}$ A köznemességet az alsótáblában a vármegyénként választott követek képviselték. L. Bölöny 1981. 32; Gudenus-Szentirmay 1989. 15.

${ }^{7}$ Részletesen 1. Gudenus-Szentirmay 1989. 20-21. A főrendiház 1918-ban megszűnt, 1926-ban felsőház néven újjáalakult (1926. évi XXII. tc., de 1944-ben véglegesen felszámolták.)

${ }^{8}$ Gudenus-Szentirmay 1989. 21.
} 
matikusan jogosult az örökös förendiházi tagságra. ${ }^{9}$ Ez a dualizmus közepi szabályozás a förenden belül jogi, gazdasági és származási vonatkozásban is húzott egy választóvonalat, amely fölé, a csúcsra egyértelmüen nem a földbirtokos főnemesség került. Vörös Károly kutatásai szerint ${ }^{10}$ 1885-ben 699 teljes jogú férfi förendiházi tagból 29\% rendelkezett ezzel a 3000 forintnál magasabb éves földadóval. Az öszszesen 205 férfi közül 8 herceg, 158 gróf, 38 báró volt. Az indigéna grófok száma a korábbi 67-ről 15 före csökkent, mely e csoport pozíciójának megingását jelzi.

A főnemesség rétegződése szempontjából a förendiházi reform legfontosabb következménye az volt, hogy 1885 és 1918 között az uralkodó olyan fönemesi címet is adományozhatott, amely az örökös förendiházi tagságra automatikusan már nem jogosított fel, ${ }^{11}$ és ezzel a förendi méltóság, valamint a fönemesi rang egyértelmüsége elvált egymástól. Werbőczy Hármaskönyvének „egy és ugyanazon nemesség” elve így a 19. század második harmadára már pusztán jogi fikció volt, és semmiféle viselkedésszociológiai osztályegységet nem takart.

Magyarország lakossága 1720 és 1787 között nem sokkal haladta meg a 2 milliót. ${ }^{12}$ Ennek - sajátos kelet-európai jelenségként Nyugathoz viszonyítva nagyszámú,

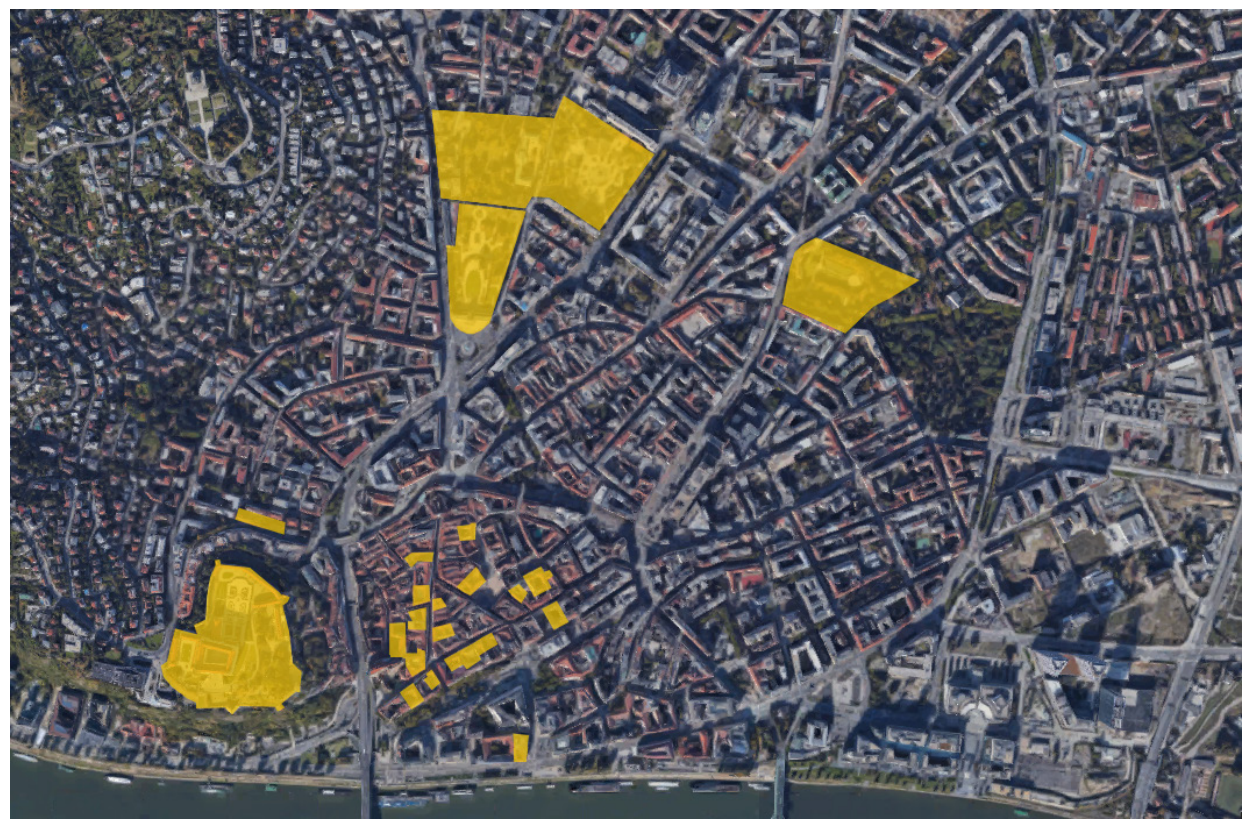

1. a) ábra. A jelentősebb pozsonyi főnemesi paloták diszpozíciója

${ }^{9}$ Bölöny 1981. 32.

${ }^{10}$ Vörös 1987. 397-407. Feldolgozta: Gudenus-Szentirmay 1989. 20-21, valamint Kövér 2006. 100-101.

${ }^{11}$ Gudenus-Szentirmay 1989. 16.

${ }^{12}$ E népesség nagy többségét - 80\%-át - a késő feudális társadalom egyik alapvető osztálya, a jobbágyság tette ki. Bővebben: Kosáry 1996. 45. 


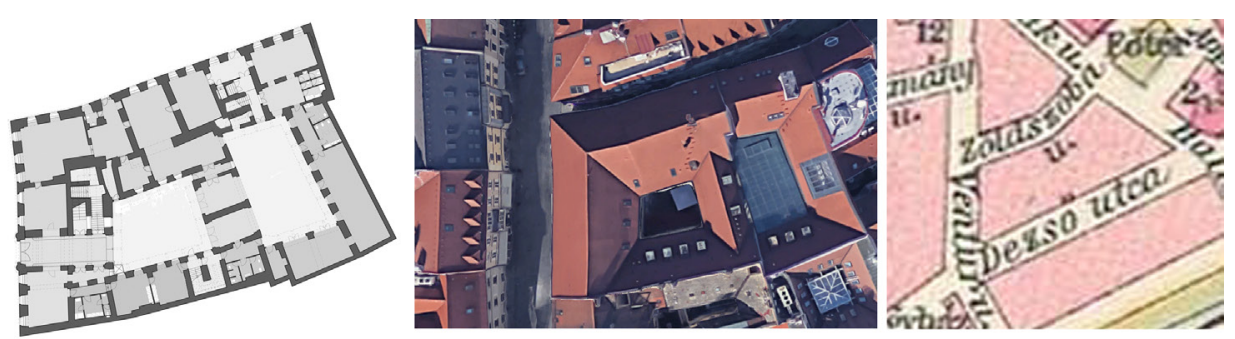

BRATISLAVA, VENTÚRSKA 27., PALÁC PÁLFFYHO, 1715
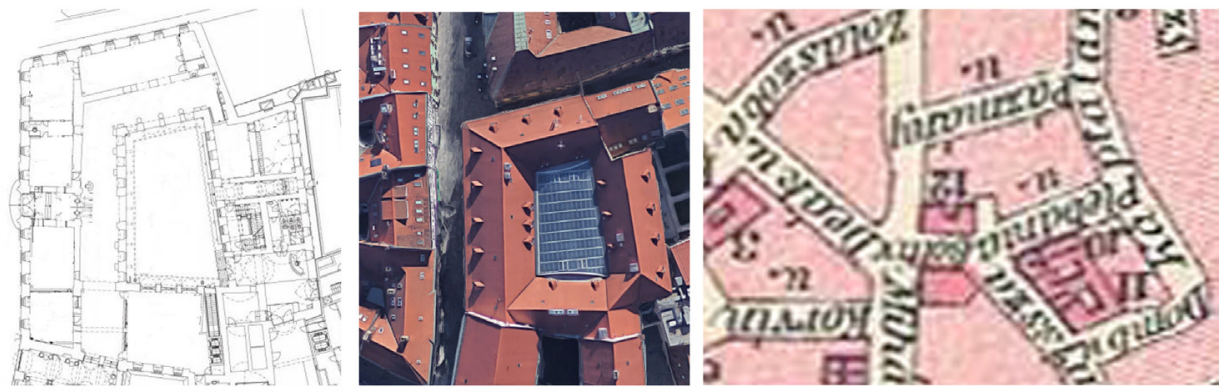

BRATISLAVA, VENTÚRSKA 15., PALÁC PAULIHO, 1775-1776
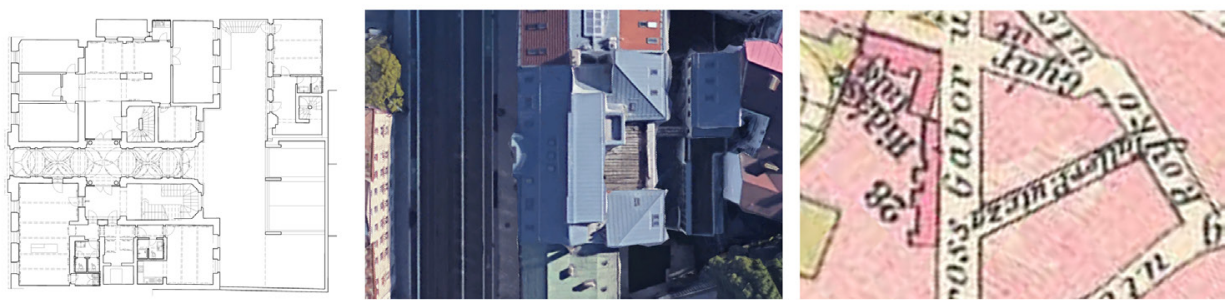

BRATISLAVA, STÚROVÁ 16. PALÁC CSÁKYHO, 1892

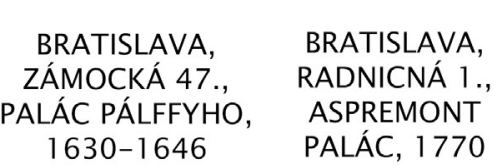
BRATISLAVA, HODZOVO 1. GRASSALKOVICOV PALÁC, 1760-1905

BRATISLAVA, SLOBODY 1., LETNY ARCIBISKUPSKY PALÁC 1614-1765
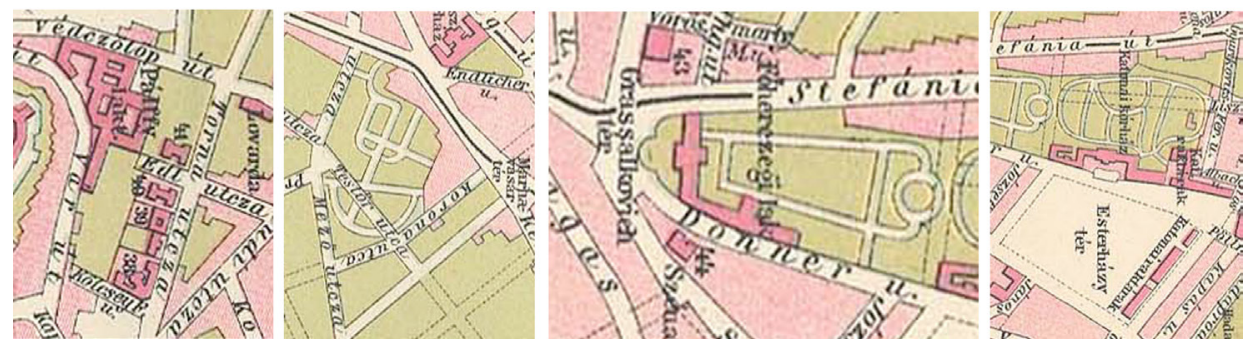

1. b) ábra. A jelentősebb pozsonyi főnemesi paloták diszpozíciója és típusai, változatokkal 
„tömeges” - 4,6-5,0\%-a adta a feudális nemességet. Ezt az okozta, hogy a 16-17. században, a török hódoltság idején, föként katonai célból sorozatban adományozott az uralkodó nemesi címet, amelyhez nem mindig járt birtok, és velük, európai mércével mérve is, komoly létszámú nemesség alakult ki. A 18. század végéig a feudális uralkodó renden, a nemességen belül szinte kizárólag a világi és egyházi főnemességé volt a politikai és társadalmi vezető szerep és a legnagyobb anyagi erő, amelynek tagjai a nemesi előjogok, a politikai szervezet, a vezető posztok, az anyagi erő, a fegyveres támasz és a jobb tájékozottság birtokában uralmuk alatt tartották mind a nemesi rend alsóbb rétegeit, mind a jobbágyságot. A nemesség legfelső szintjén 70-80, valamivel bővebben számítva az egész országban mintegy 200 család tartozott a fönemességhez. A fönemesek köre a 18. század végére bizonyos fokig módosult. Egyrészt a nemesi árutermelés növekedésével a vagyonosabb birtokosok kezdtek terményeik, boruk eladásában, exportjában, sőt végül részben már a belső piac, tehát az ipar fejlesztésében is érdekeltté válni. ${ }^{13}$ A $25-30$ ezer köznemes család jobb módú, felső rétege megerősödött, önállósodni kezdett, és 1790 körül már igényt tartott - nem is egészen eredmény nélkül - a hatalomban való részvételre. Másrészt az 1760-as évektől a főnemesek köre a befolyásosabb köznemesek - akik nem ősi vagyoni és társadalmi pozíciók birtokában, hanem hivatali érdemekért kaptak grófi, bárói címet - csoportjával bővült. A 18. század végétől 1848-ig terjedő időszakban a nemesítetteknek körülbelül 70\%-a hivatalnok és katona volt. A nemesi cím 1848 után is adományozható volt egészen 1918-ig, amikor még IV. Károly király (1916-1918) is adományozott címeres levelet. Az 1867-1918 között nemesi címet kapó 204 fö 40\%-a magyar, 22\%-a német, 18\%-a zsidó, $14 \%$-a szláv, míg 6\%-a zömében a többi hazai nemzetiségből került ki. Az új fönemesek (homo novus) 38\%-a a gazdasági élet különböző posztján helyezkedett el, vagy ügyvéd, közjegyző volt. $31 \%$ volt katona és $21 \%$ hivatalnok. A tudomány képviselői $8 \%$-kal szerepeltek. Látható, hogy a dualizmus kori, I. Ferenc József király (1848-1916) politikájából eredő hivatalnok- és katonanemesítés tulajdonképpen egyenes folytatása volt az 1848 elötti, közvetve a 18. századi nemesi címadományozásnak. 1848 előtt a hazai főnemességet - a német birodalmi, osztrák vagy olasz rangok engedélyezett vagy részben szokásjogon alapuló használatát is figyelembe véve - mintegy 600 család, 3 hercegi, 91 grófi és 115 bárói nemzetség alkotta. ${ }^{14} \mathrm{~A}$ dualizmus korában azonban - viselkedésszociológiai értelemben - már nem önmagában a nemesi cím adományozása jelentette a legfontosabb társadalmi rétegformáló tényezőt. ${ }^{15}$

A társadalomtörténet-írás ma úgy tartja, hogy Magyarország társadalmának feudális rendi struktúrája - jóllehet bomlása már 1848-1849-et megelőzően elkezdődött - a régi rendszer forradalmi felszámolásával nem semmisült meg azonnal, hanem 1849-1867 között - szoros kölcsönhatásban a gazdasági fejlödéssel és a Habsburg-

\footnotetext{
${ }^{13}$ Mária Terézia több tucat kereskedőcsaládnak, telepesnek adott nemesi kiváltságlevelet. Bővebben: Gudenus-Szentirmay 1989. 24.

${ }^{14}$ Baji-Csorba 1994. 5.

${ }^{15}$ Kövér 2006. 101-102.
} 
uralkodóktól függő ország politikai viszonyainak változásával - fokozatosan alakult át. „Minden társadalomnak olyan az osztálytársadalma, amilyen a rendisége volt.”16 Különösen igaz ez a 19. században, a történeti-jogi értelemben vett rendiség változása idején, amikor a nemesi rend a jobbágyfelszabadítás és közteherviselés intézményesített jogi aktusával (1848, illetve az 1853. évi úrbéri pátens) való megszüntetése egy csapásra nem eredményezte a mögötte meghúzódó viselkedésszociológiai értelemben vett rendiség lerombolását is. A nemesség feudális társadalomszerkezete tehát a 19. században különösen lassan módosult, és ebben a fónemesség a hagyományos rendi formáiba zárkózva sokáig élt együtt a mellette, de jórészt nem belöle kifejlődő nagypolgárság - tőkés mágnások, nemesített állami tisztviselők, katonák új osztályával. A főnemesség esetében a korszakban a társadalmi állapot és az osztályhelyzet nem tért el látványosan egymástól, s ez okozta, hogy a tradicionális társadalmi vezető réteg struktúrájának óvása mellett indult meg a társadalom 1848-cal, illetve 1867-tel lezajló intézményes és politikai, majd a dualizmus korában gazdasági modernizációja is. ${ }^{17}$

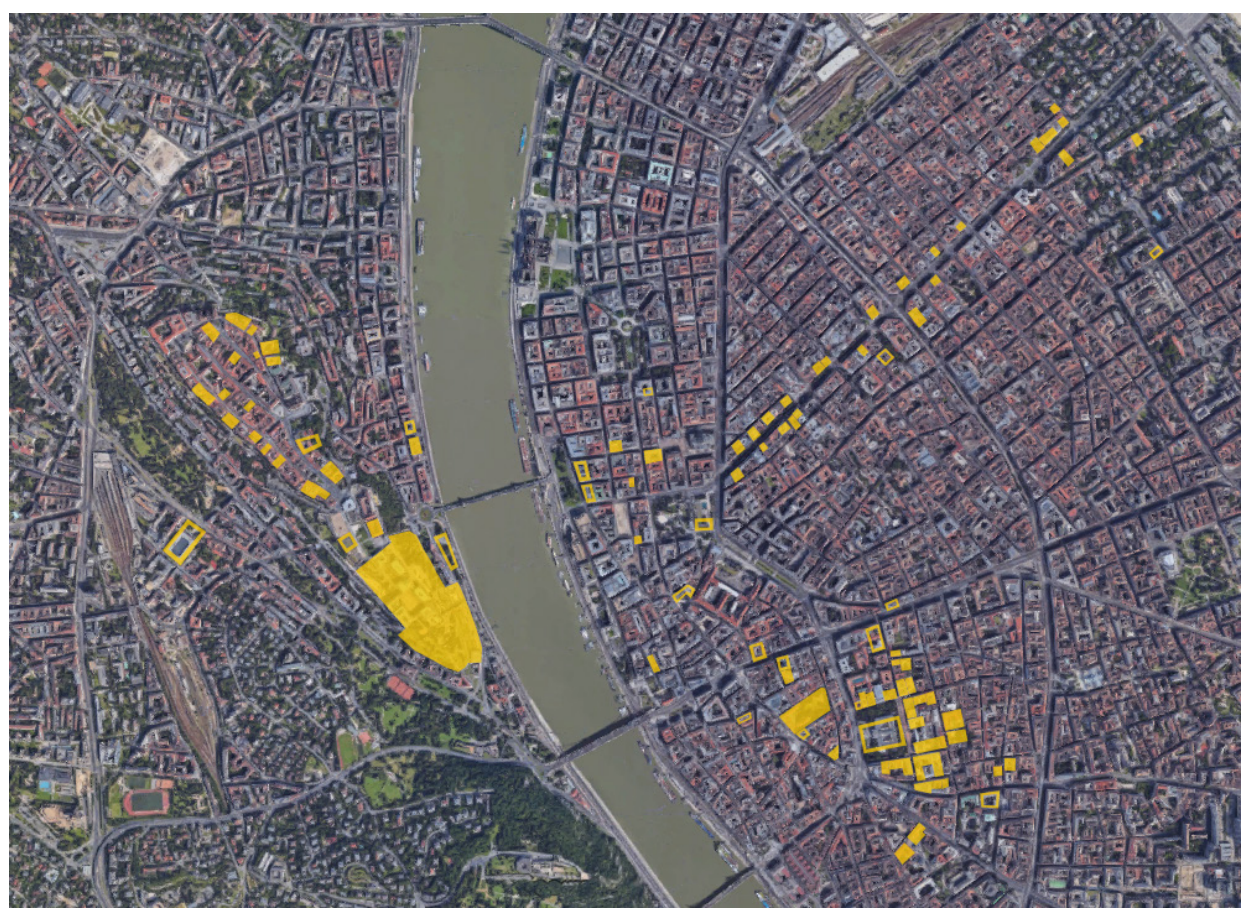

2. a) ábra. A budai és a pesti, illetve a budapesti jelentősebb fő́ri paloták diszpozíciója

${ }^{16}$ Hajnal István megállapítását idézi: Kövér 2006. 34-35.

${ }^{17}$ Erdei Ferenc és Leopold Lajos társadalomtörténeti koncepcióját összeveti: Kövér 2006. 24-25. 


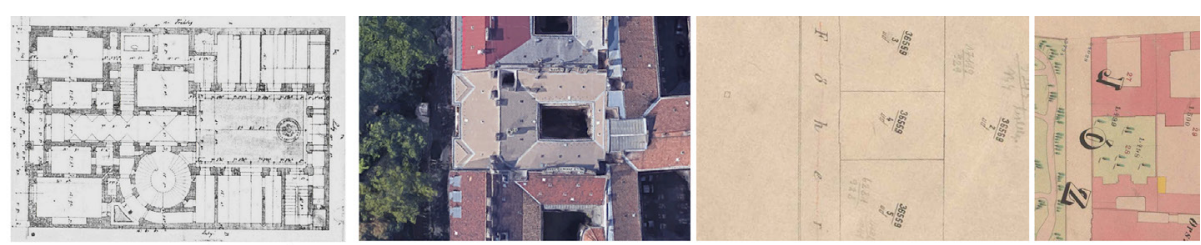

BUDAPEST, BRÓDY SÁNDOR UTCA 4., DESSEWFFY-PALOTA, 1875

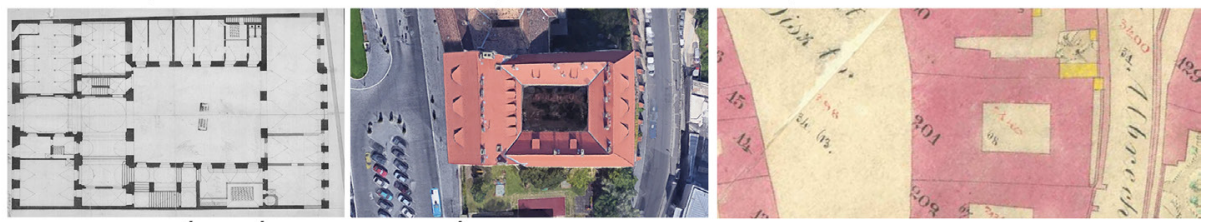

BUDAPEST, DÍSZ TÉR 3., BATTHYÁNY-PALOTA, 1689-1873

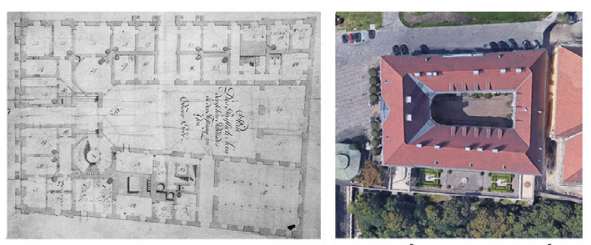

BUDAPEST, SZENT GYÖRGY TÉR 1-3., SÁNDOR-PALLAVICINI-PALOTA, 1803-1867

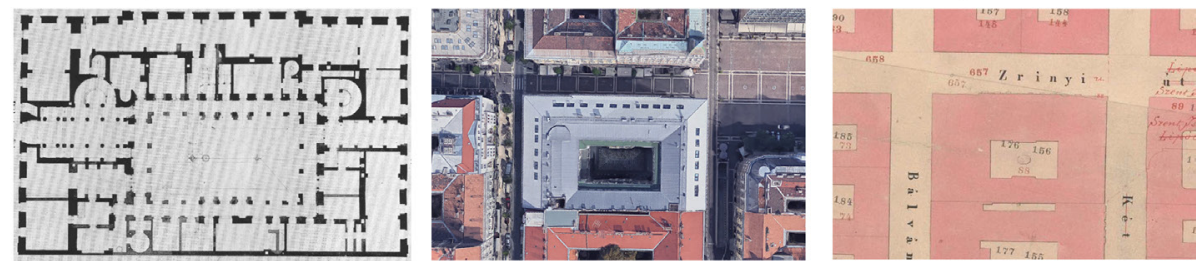

BUDAPEST, OKTÓBER 6. UTCA 7., MARCZIBÁNYI-PALOTA, 1830-1868

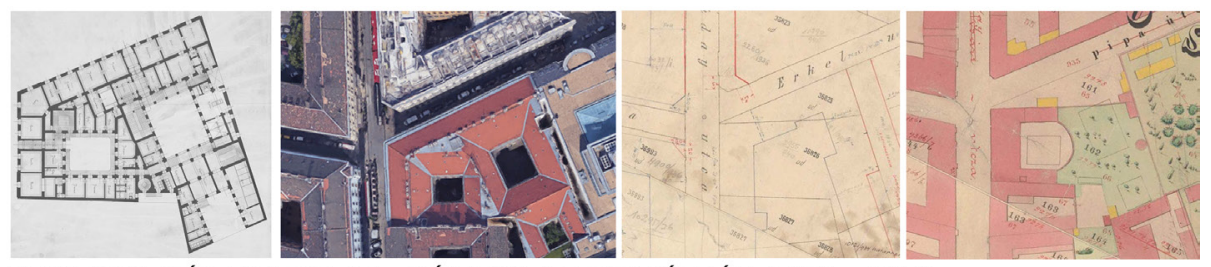

BUDAPEST, RÁDAY UTCA 18., KÁROLYI-PALOTABÉRHÁZ, 1875-1876

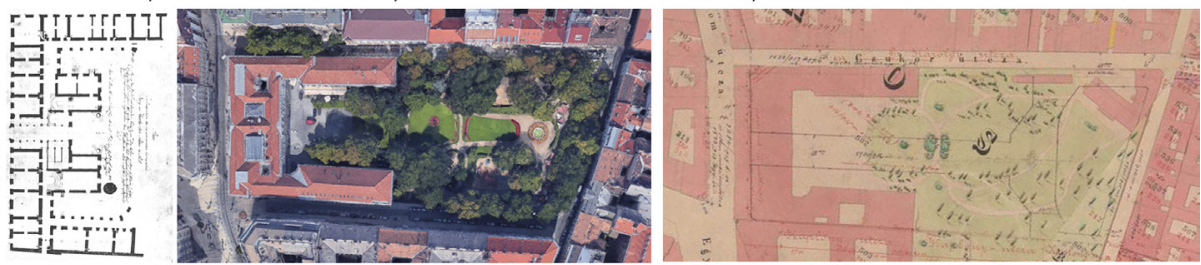

BUDAPEST, KÁROLYI MIHÁLY UTCA 16., KÁROLYI-PALOTA, 1696-1928

2. b) ábra. A budai és a pesti, illetve a budapesti jelentősebb fóúri paloták diszpozíciója és típusai, változatokkal 

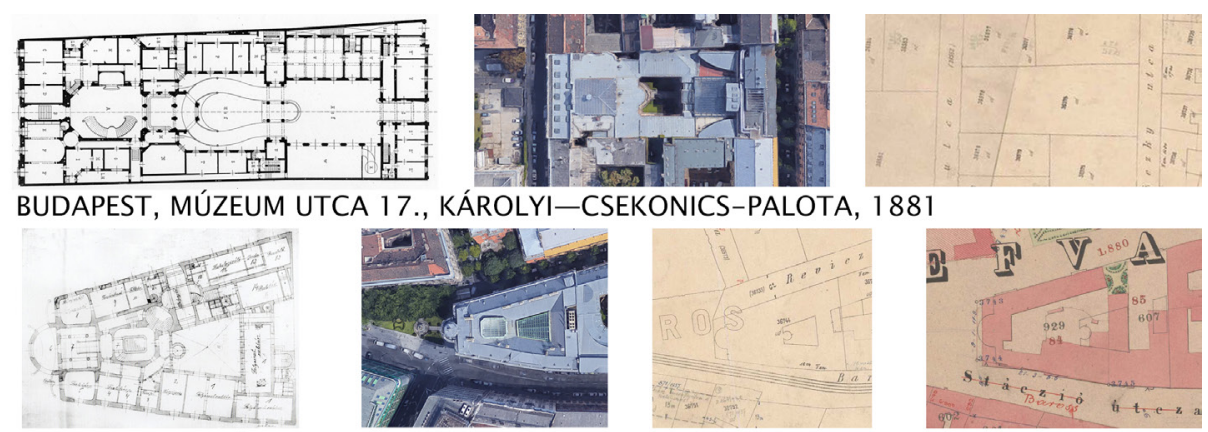

BUPAPEST, SZABÓ ERVIN TÉR 1., WENCKHEIM-PALOTA, 1887-1927
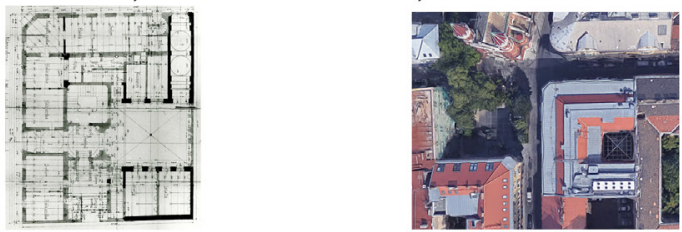

BUDAPEST, LŐRINC PAP TÉR 2., ZICHY-PALOTA, 1899-1935
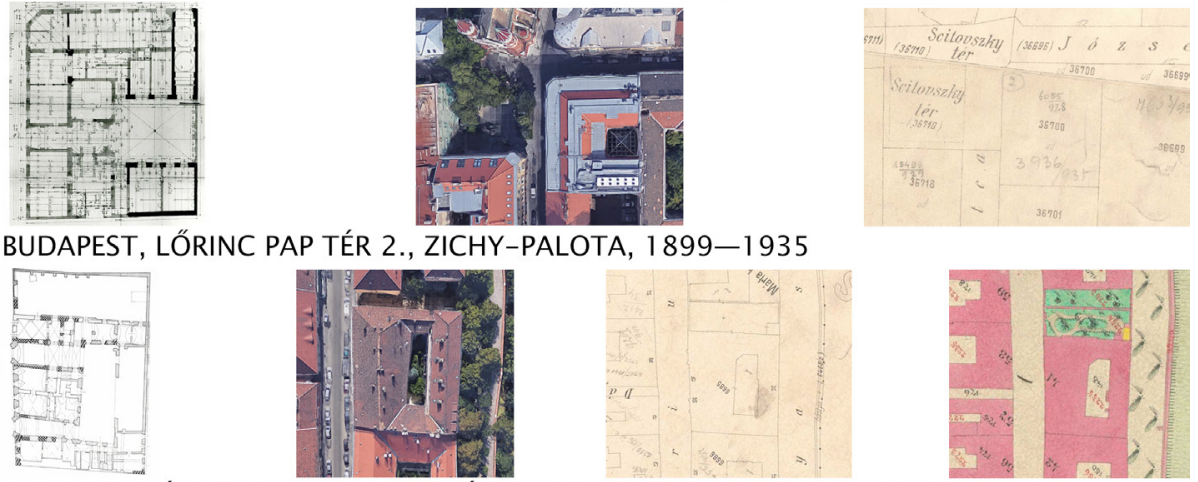

BUDAPEST, ÚRI UTCA 48-50., BERÉNYI-ZICHY-PALOTA, 1737-1810
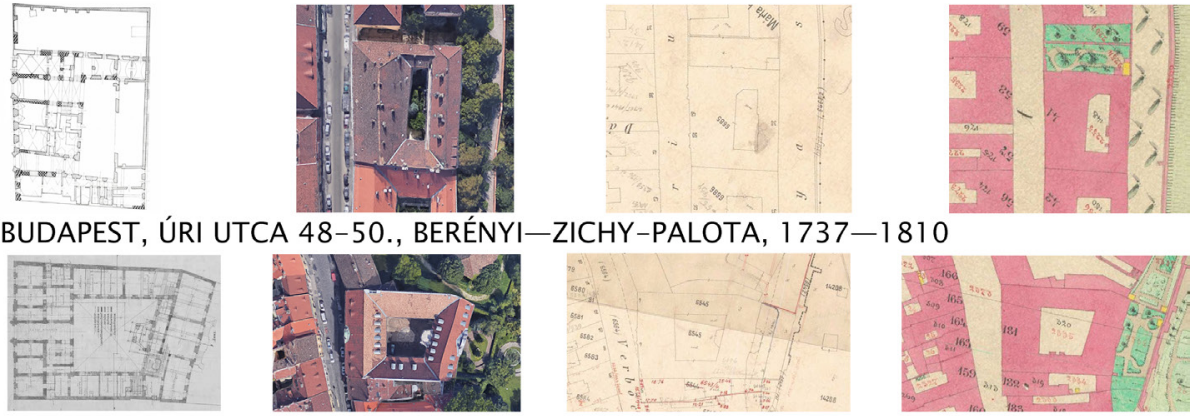

BUDAPEST, TÁNCSICS MIHÁLY UTCA 7., ERDŐDY-HATVANY-PALOTA, 1750-1913
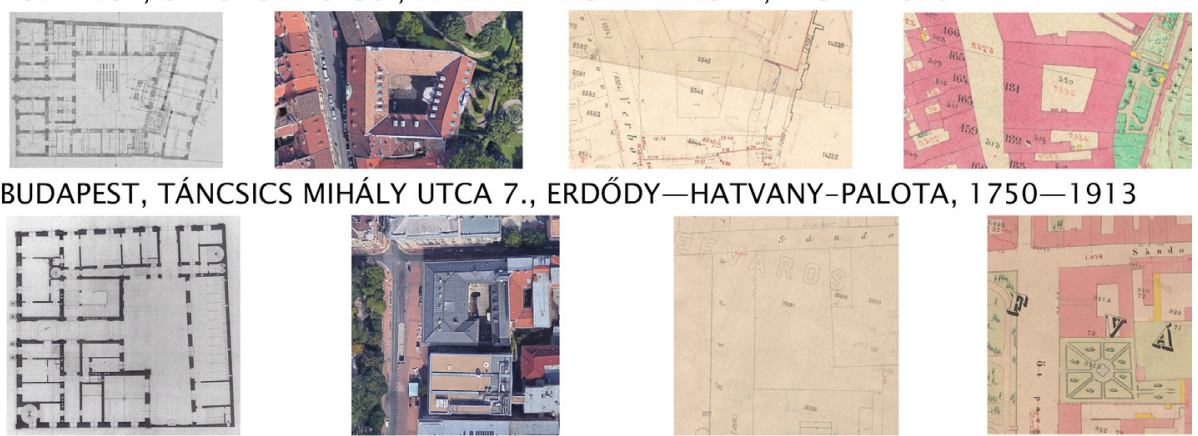

BUDAPEST, POLLACK MIHÁLY TÉR 3., FESTETICS-PALOTA, 1862-1865
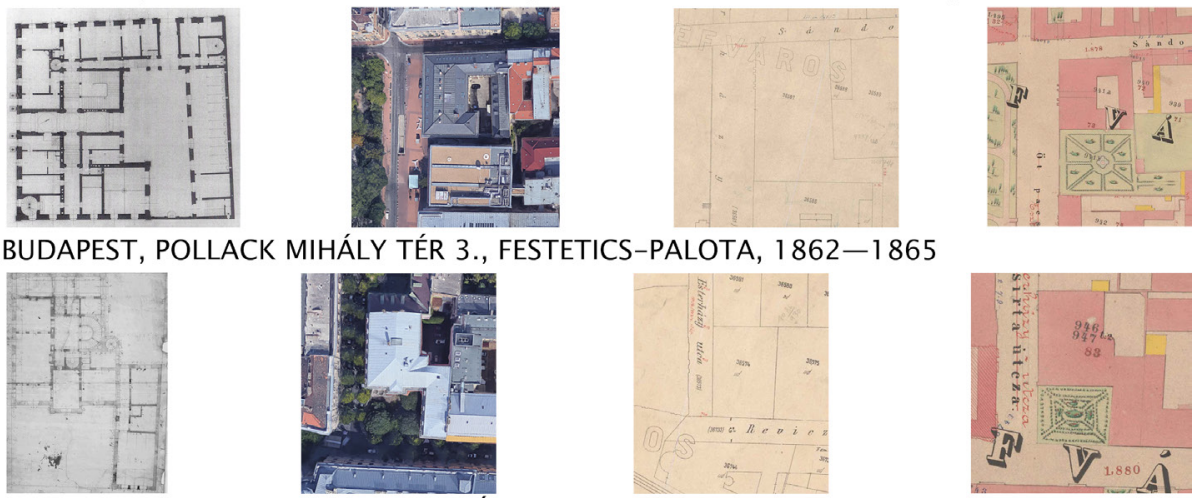

BUDAPEST, ÖTPACSIRTA UTCA 4., PÁLFFY-PALOTA, 1867-1870

2. b) ábra. A budai és a pesti, illetve a budapesti jelentősebb fớri paloták diszpozíciója és típusai, változatokkal (folytatás) 


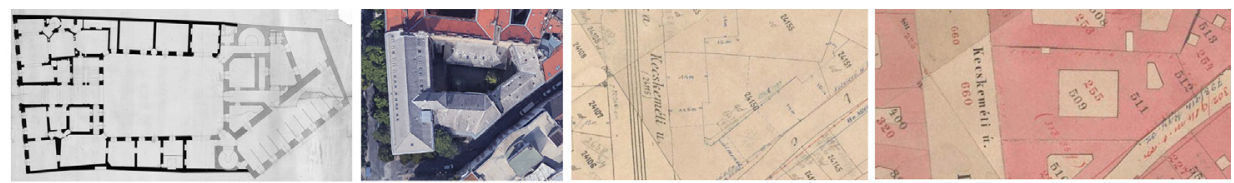

BUDAPEST, KECSKEMÉTI UTCA 10., VOLT CSEKONICS-PALOTA, 1797-1864
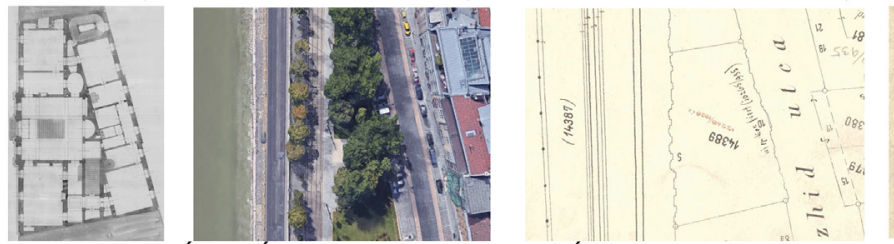

BUDAPEST, LÁNCHÍD UTCA 10., VOLT SZÉCHENYI-PALOTA, 1851-1945

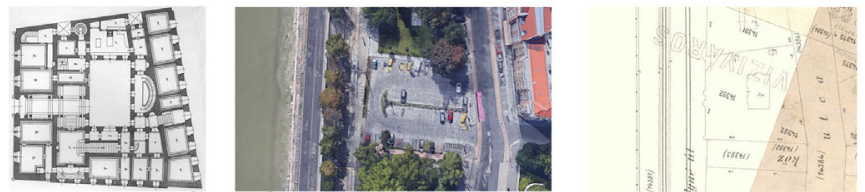

BUDAPEST, LÁNCHÍD UTCA 4., VOLT LIPTHAY-PALOTA, 1872-1949
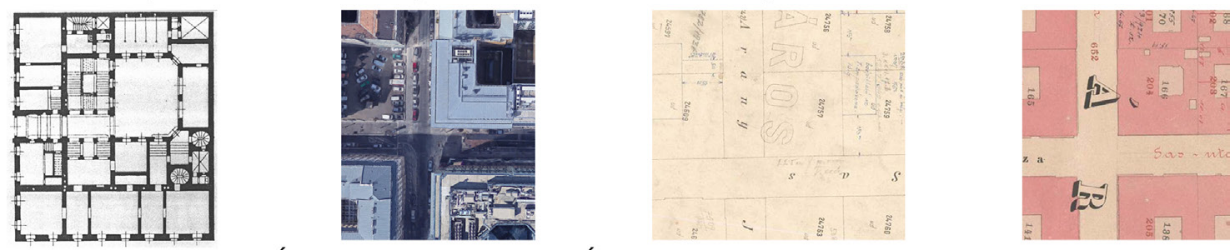

BUDAPEST, ARANY JÁNOS UTCA 24., WODIÁNER-PALOTA, 1868-1899
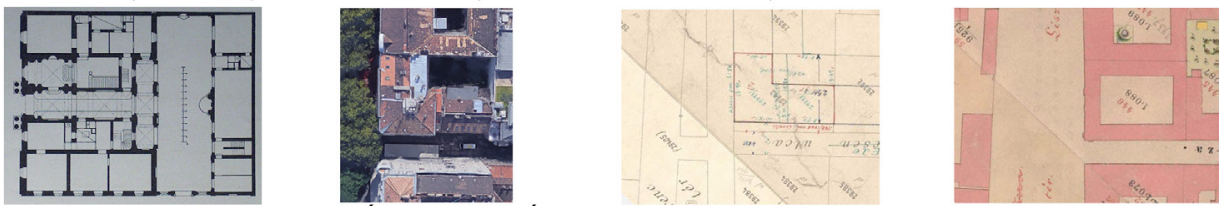

BUDAPEST, LISZT FERENC TÉR 3., WODIÁNER-PALOTA, 1889-1941

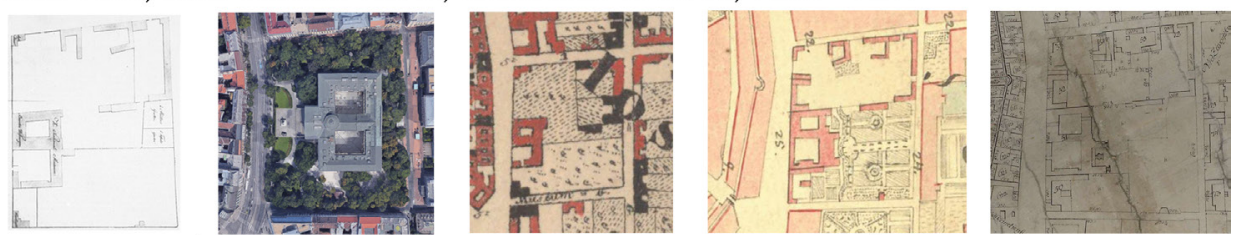

BUDAPEST, MÚZEUM KÖRÚT 16., VOLT KLOBUSICZKY-BATTHYÁNY-PALOTA, 1751-1838

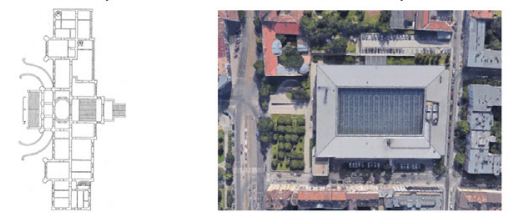

BUDAPEST, KRISZTINA KÖRÚT 55., VOLT KARÁCSONYI-PALOTA, 1853-1938

3. ábra. A lebontott budapesti fóuri paloták példái a típusok szerint 


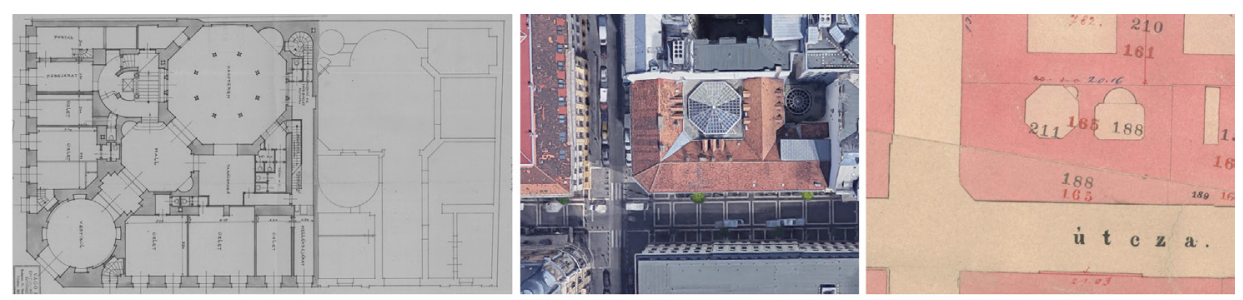

BUDAPEST, ZRÍNYI UTCA 8-10., FESTETICS-PALOTABÉRHÁZ, 1820-1827
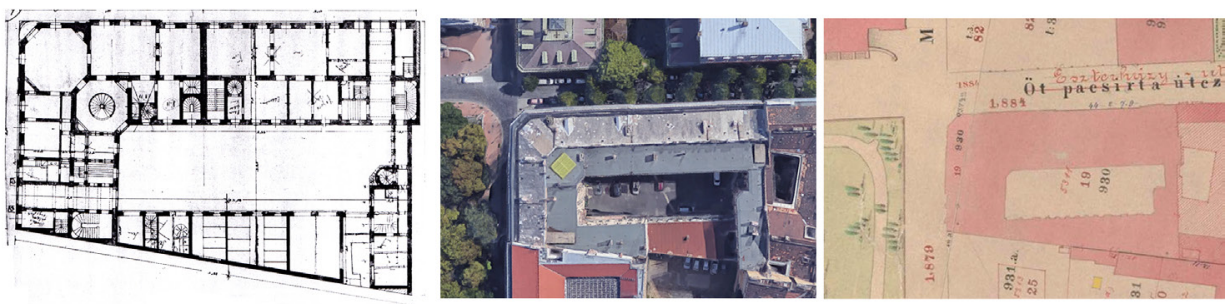

BUDAPEST, MÚZEUM UTCA 11 ., KÁROLYI-PALOTABÉRHÁZ, 1869
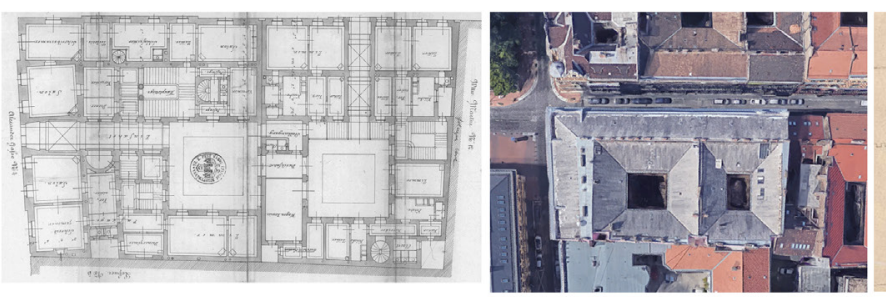

BUDAPEST, BRÓDY SÁNDOR UTCA 14., DEGENFELD-PALOTABÉRHÁZ, 1872-1874
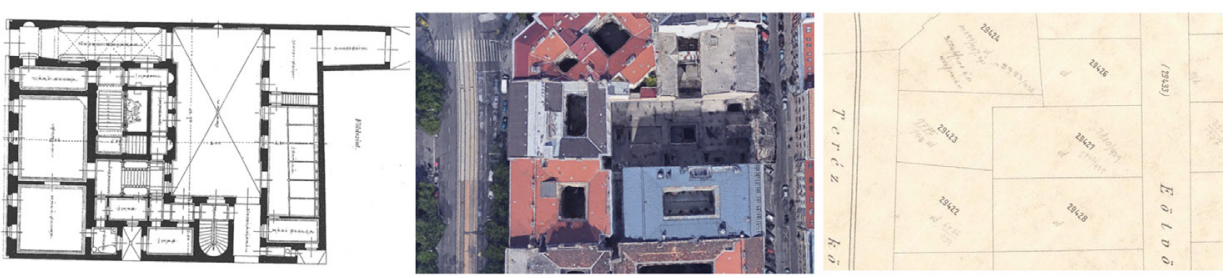

BUDAPEST, TERÉZ KÖRÚT 11-13., BATTHYÁNY-PALOTABÉRHÁZ, 1884
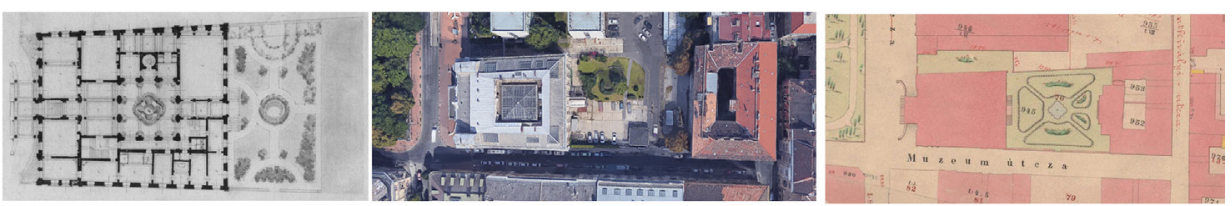

BUDAPEST, POLLACK MIHÁLY TÉR 10., KÁROLYI-PALOTA ÉS -BÉRHÁZ, 1869-1871

4. ábra. A budapesti palotabérházak példái 
A 18. században a fönemesség egy része Bécsben és Pozsonyban, elsősorban magyar udvari kancelláriai vagy kamarai tisztségek birtokában élte a Habsburg-udvari főurak reprezentatív életét, és csak alkalmanként vagy szezonálisan töltött idöt magyarországi vidéki birtokán. Mások viszont ezeken a vidéki birtokokon rezideáltak, próbálták a 18. századi új, világi, felvilágosult életforma helyi változatát megteremteni. A nemességet így egy másik belső választóvonal is megosztotta, nevezetesen az „udvarképesség”. Akik az udvarképesség (Hoffähigkeit) birtokában voltak, tehát a királyi udvar szertartásain részt vehettek, azok jelentették a viselkedésszociológiai értelemben vett legfelső fönemesi réteget. Az udvarképesség egy pontosan körülírt, leírhatóan müködő mechanizmus volt, ${ }^{18}$ amely szerint a társadalom felső rétegének tagjai között részben hivatali szolgálat, részben örökölt társadalmi státus, részben pillanatnyi funkció, részben pedig bizonyos kiérdemelt címek alapján világos belső határvonalat húzott. Már a 18. század óta a francia, illetve spanyol mintára kialakult udvari etikett szabályozta, hogy ki, mikor volt köteles megjelenni, illetve jelenhetett meg egy udvari rendezvényen. Például a nyilvános audiencián, a királyi kihallgatáson, a dualizmus idején az állami tisztviselők közül a kinevezést kapó miniszteri osztálytanácsosok feletti posztokon, hasonlóan a kitüntetettekhez személyesen kellett megjelenni. Illett évente legalább egyszer elmenniük mindazoknak, akik az udvartartás belső ranglétrája szerint vagy valóságos belső titkos tanácsosok, vagy udvari kamarások voltak. Ezeket a címeket az uralkodó adományozta bizonyos szolgáltatások fejében. A, ,valóságos belső titkos tanácsos” kitüntetést miniszterek, főpapok, tábornokok és diplomaták kapták, kérelmezni nem lehetett. A „császári és királyi kamarás" méltóságért viszont folyamodni kellett, a családfán 16 nemes őst felmutatva, a kamarási adót befizetve lehetett megkapni. Végül az audiencián megjelenhettek a kinevezett miniszterek, a parlamenti képviselők, illetve az osztrák és magyar delegációk tagjai, de ezek meghívása értelemszerủen csak személyüknek és csak mandátumuk vagy megbízásuk időtartamára szólt. ${ }^{19}$

Az első pozsonyi országgyülést (a rendi állam törvényelőkészítő fórumát) 1402ben Zsigmond király tartotta a Duna partján emelkedő királyi várban. Az 1536. évi országgyülés kimondta, hogy a magyar kormány székhelye, az ország fővárosa Pozsony legyen. A 16. században 43 országgyülést tartottak a királyi várban. A mohácsi csata után a vár délnyugati tornyában örizték a Szent Koronát. A legtöbb koronaőrt a jelentős befolyású gróf Pálffy család adta. A királyi vár mai formáját is meghatározó átépítése 1552-től 1556-ig tartott. ${ }^{20}$ 1580. december 23-án Pozsony vármegye föispánjává Pálffy II. Miklós (1552-1600) grófot nevezték ki, aki egyúttal Niklas Salm $(† 1550)$ gróf halála után a vár megürült fökapitányi tisztét is betöltötte; Habsburg Rudolf király pedig 1599. július 24-én Pozsony vármegye örökös főispán-

${ }^{18}$ A 17-18. századi mintaadó francia királyi udvar müködéséről: Elias 2005; a francia Versailles és ennek hatása alatt álló bécsi Hofburg udvari életéről összefoglaló: Graf 2002. 95-116.

${ }^{19}$ Kövér 2006. 101.

${ }^{20}$ Komora 2002. 6-13. 
ságával és Pozsony várának örökös fökapitányságával jutalmazta. Az időközben megrongálódott királyi vár helyreállítási munkálatainak felügyelésével az 1630. évi országgyülés saját elnökét, Pálffy II. Miklós gróf fiát, Pálffy III. Pál (1592-1653) nádort és országbírót (1646-1649) bízta meg 1632-től. Az irányítása alatt felépített királyi vár közel két századon át állt fenn, és országos fontosságú események színhelye lett. ${ }^{21}$ A gróf magánpalotáját és pompás kertjét a királyi vár szomszédságában (ma Zámocká 47. szám alatt) építtette fel 1635-ben. 1634-ben adományul kapta Detrekő várát, 1635-ben megszerezte a dévényi, 1645-ben a bajmóci, valamint az ausztriai Marchegg-uradalmat. Birtokait mintaszerü gazdaságokká alakította át. 1635-től a királyi palotán dolgozó olasz, német mesterekkel magánbirtokai központjában álló kastélyait (Bajmóc, Malacka, Vöröskő) is átalakíttatta. ${ }^{22}$ A Pálffy család 1715-ben vásárolta meg a (ma Panská 261/19. szám alatt) található palota előzményéül szolgáló épületeket. A Ventúrska és Zelená utca sarkán (ma Ventúrska 274/10. szám alatt) szintén egy régebbi házból, gróf Pálffy Lipót (1716-1773) tábornok megbízásából, 1747-ben átépített palota áll. A mai Panská és Ventúrska utcák, a pozsonyi vár alatti, középkori Szent Márton-dóm közelében, a pozsonyi óváros központját adják. Ezekben az utcákban és a kapcsolódó épülettömbökben számos foúri palota áll. A két utca találkozásánál (ma Ventúrska 269/1. szám alatt) található gróf Erdődy György (1645-1713) országbíró hajdani palotája, amelynek szomszédságában (ma Panská 258/27. szám alatt) báró Keglevich József (1700-1763), Torna megye föispánjának palotája emelkedik. A közeli vár alatti Szent Márton-dómban gróf Esterházy Imre (1663-1745) esztergomi érsek, főkkancellár és Pálffy János (1663-1751) nádor Habsburg Mária Teréziát 1741. június 25-én királynővé koronázta, aki később szívesen tartózkodott a várban. Leánya, Habsburg-Lotaringiai Mária Krisztina (1742-1798) főhercegnő 1766-ban költözött férjével, Albert Kázmér (1738-1822) szász-tescheni herceggel a királyi várba. Az Esterházy család 1743-ban építtetett palotája a mai Panská 245/13. szám alatt található. 1775-ben gróf Zichy Ferenc (1749-1812) föispán és föpohárnokmester a közelben (ma Ventúrska 265/9. szám alatt) építtetett palotát, amelynek során felhasználták a korábban itt állt gótikus polgárház maradványait. A piactér (ma Hlavné námestie) szomszédságában, az óváros központi részén (ma Primaciálne námestie 494/2. szám alatt) korábbi, 16. századi palota felhasználásával, 1778 és 1781 között építtette fel gróf Batthyány József (1727-1799) bíboros és esztergomi érsek a prímási palotát, amelynek nagytermében ülésezett a reformkori kétkamarás országgyülések felsőtáblája. 1802-1848 között az alsótábla ülései a Magyar Királyi Kamara közeli épületében (ma Michalská 263/1. szám alatt) zajlottak (1. ábra).

Pozsony fallal körülvett belvárosától északra, a városfalakon kívül (ma Námestie slobody 2899/1. szám alatt), a 16-17. század fordulóján, gróf Forgách Ferenc

\footnotetext{
${ }^{21}$ Itt ismertetett el a Habsburg-ház örökösödési joga 1687-ben, és itt köttetett a III. Károly-féle pragmatica sanctio, melyet Pálffy V. János gróf (1664-1751) nádor és fővezér - horvát bánként - előbb maga szavaztatott meg horvát területen, majd fogadtatott el a magyar föúri rendekkel.

${ }^{22}$ Markó 2000. 237.
} 
(1560-1615) bíboros és esztergomi érsek vásárolta meg az érseki nyári palota telkét, és a mai palota helyén létrehozta a később méltán híressé vált, az ország legelső, tudományosan is leírt kertjét. 1614-től valószínüleg már itt volt az érseki székhely is, ahol gróf Lippai György (1600-1666) esztergomi érsek 1642-1666 között új palotát építtetett és fejlesztette a kertet is. 1761-1765 között gróf Barkóczy Ferenc (1710-1765) esztergomi érsek, helytartósági tanácsos utasítására a palotát átépítették és bővítették. E palota szomszédságában (ma Hodžovo námestie 2978/1. szám alatt) kerttel övezve építtette fel 1760-ban gróf Grassalkovich Antal (1694-1771) koronaör, a Magyar Királyi Kamara elnöke, királyi személynök a saját palotáját. A közelben (ma Špitálska 2216/24. szám alatt) fekvő, korábbi Erdődy-kertet az 1755. évi 47. törvénycikkben magyar indigenátust nyert gróf Johann Nepomuk

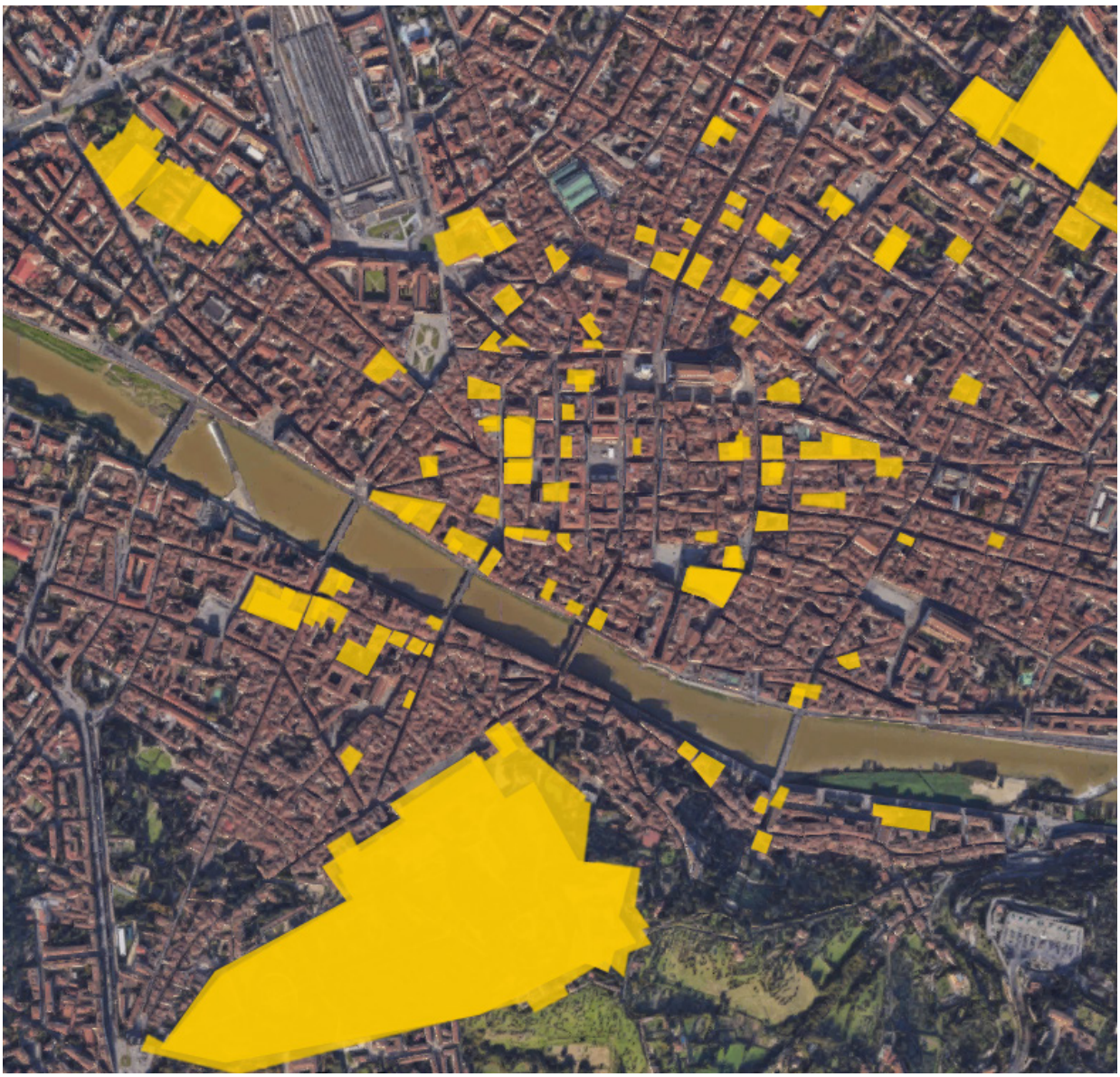

5. a) ábra. A firenzei paloták diszpozíciója 


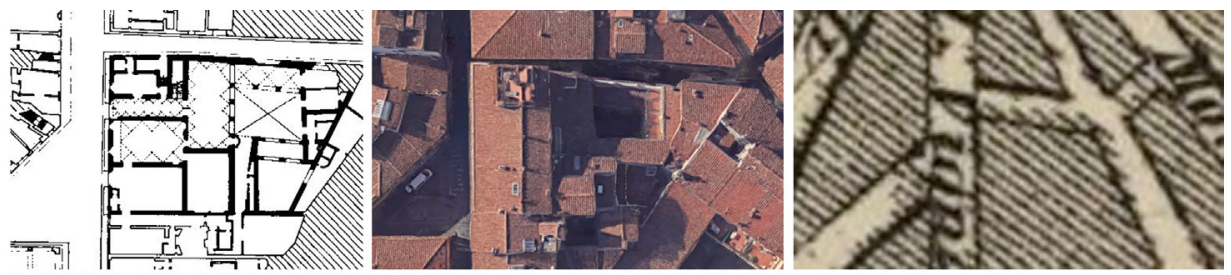

FIRENZE, VIA DELLA VIGNA NUOVA 18., PALAZZO RUCELLAI, 1446-1451

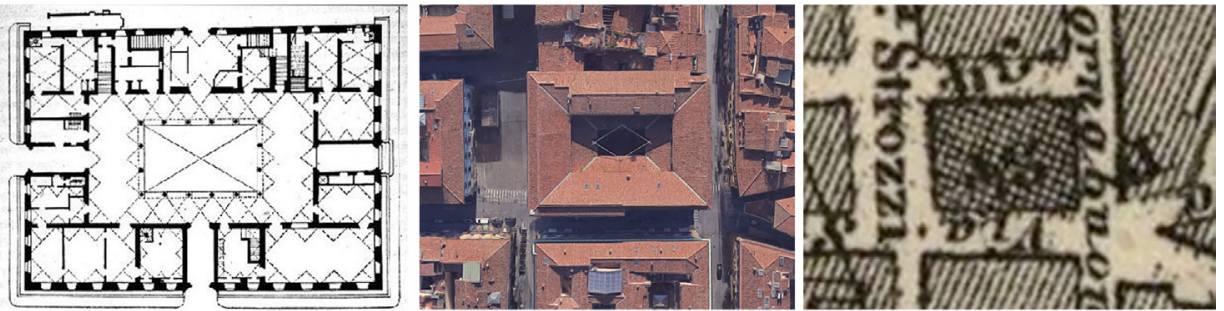

FIRENZE, PIAZZA DEGLI STROZZI, PALAZZO STROZZI, 1489-1538
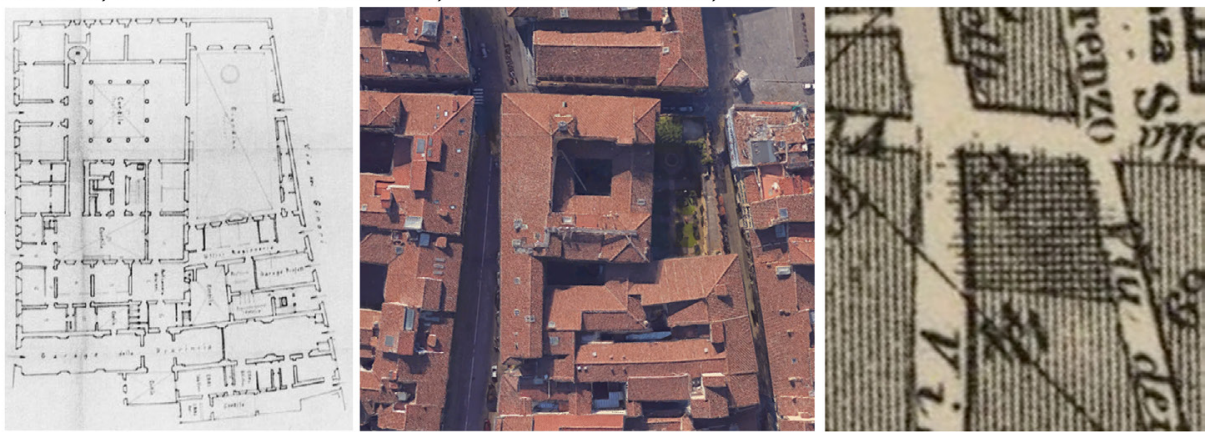

FIRENZE, VIA CAMILLO CAVOUR 3., PALAZZO MEDICI-RICCARDI, 1444-1650
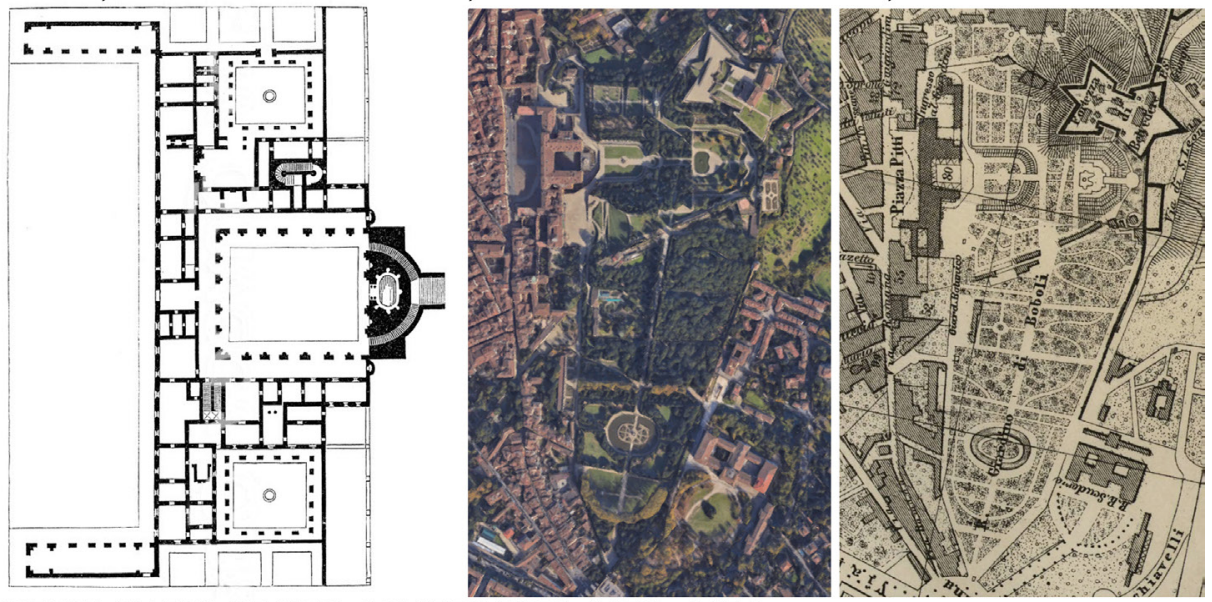

FIRENZE, PIAZZA DE PITTI, PALAZZO PITTI, 1458-1574

5. b) ábra. A firenzei paloták diszpozíciója és típusai, változatokkal 
Gobert von Aspremont-Lynden (1757-1819) császári és királyi kamarás vásárolta meg, és 1770-ben itt építtette fel a nyári palotáját.

Magyarország török megszállását követően, 1686 után hosszú ideig fel sem merült, hogy Buda újra királyi székhely legyen. ${ }^{23}$ 1748-ban gróf Grassalkovich Antal (1694-1771) kamaraelnöknek sikerült megnyernie Mária Terézia királynőt, aki engedélyezte egy új királyi palota felépítését. Az építkezések már a következő évben megindultak, és 1768-1769-re fejeződtek be teljesen. A palotát - amely akkor még kivitelezés alatt volt - a királynő kétszer, 1751-ben és 1764-ben látogatta meg, de csak a második alkalommal használta szállásként. Ezután alkalmi rezidenciaként Albert Kázmér szász-tescheni herceg, Magyarország helytartója vette igénybe 17661777 között. 1784-töl II. József király döntése alapján 1791-ig a palotában helyezték el a Pozsonyból ideköltöztetett Főhadparancsnokságot, ezzel a palota részben visszanyerte régebbi kormányzati és adminisztratív vezető szerepét. A budai palota szimbolikus jelentőségét növelte az uralkodónak az a döntése is, melynek nyomán Bécsből ide hozták vissza, és itt őrizték - több-kevesebb folyamatossággal - a Szent Koronát. Ezt követően, II. Lipót király idején, a palota újra rezidenciaként kezdett müködni, amikor Habsburg-Lotaringiai Sándor Lipót (1772-1795) főherceg nádor a palotába költözött, majd 1795 után öccse, József (1776-1847) föherceg követte elöbb helytartói, majd nádori minőségben haláláig. Ekkor már az uralkodói család is többször felkereste a palotát. 1820-tól temetkezőhelyként kezdték használni a Szent Zsigmondkápolna altemplomát, majd 1830-tól kriptának építtették át. 1852-ben itt szállt meg Ferenc József császár, de újra uralkodói rezidencia szerepet csak 1856-ban kapott, amikor a déli szárnyban alakították ki Habsburg-Tescheni Albert (1817-1895) főherceg kormányzó és felesége, Wittelsbach Hildegárd Lujza (1825-1864) királyi hercegnő lakosztályát. Albert 1866-ig lakott itt, és távoztával a déli szárnyból királyi lakosztály lett. A kiegyezés után a királyi pár többszöri látogatása során kiderült, hogy a palota az udvari reprezentációhoz szükös, és szükséges lenne a kibővítése. A palota bővítése és berendezése 1890-től kezdődően 1904-re fejeződött be. Az 1918 októberéig IV. Károly által használt palotába 1921-ben az ország kormányzója, Horthy Miklós költözött, aki azt 1944-ig használhatta. ${ }^{24}$

A királyi palota közvetlen közelében (ma Szent György tér 4. szám alatt) gróf Teleki I. József (1738-1796) föispán, koronaőr palotája állt, amelyet 1787 után és 1788-1789 között is átépíttetett. A palotát 1857-töl Habsburg-Lotaringiai József Károly Lajos (1833-1905) főherceg rezidenciájaként használták és 1869-1870 között átalakították. 1892-től Habsburg József Ágost (1872-1962) föherceg palotája volt, amelyet 1901-1906 között teljesen átépítettek és korszerüsítettek. A tér keleti oldalán (ma Szent György tér 1-2. szám alatt) található palotát korábbi épített elözmények felhasználásával gróf Sándor Vince (†1822) császári-királyi kamarás épít-

\footnotetext{
${ }^{23} \mathrm{Az}$ elemzéshez felhasznált pest-budai történeti térképek gyűjteményét adja: Holló 1994; a pest-budai palotákra vonatkozó legfontosabb adattárak és várostörténeti összefoglalások: Siklóssy 1931; Merényi 1955. 667-669 (Magánpaloták és luxusvillák), 622-644 (Budapesti magánbérházak); Lőrincz 1999. 253-259.

${ }^{24}$ Bánrévy 1952. 1-49; F. Dózsa 2001.
} 
tette 1803-1807 között. A palota 1856-ig az örgróf Pallavicini család tulajdonában, majd 1867-ig Habsburg-Tescheni Albert (1817-1895) föherceg használatában volt (2-3. ábra).

A bécsi kormányzat 1783-ban határozta el, hogy az Országház és Úri utcák közötti, a budai Vár területén, a Várkerületben elhelyezkedő (ma Országház utca 28. szám alatti) épületegyüttest a királyi tábla, a hétszemélyes tábla, valamint az országgyülés céljaira veszi igénybe. Mivel az Országház utcai szárnyában az országgyűlési termek építése elhúzódott, 1784 végére az alsó tábla gyülésterme készült el. A munkálatok 1785 végére fejeződtek be. Az országgyülési termek egy évszázad alatt csupán három ízben, 1790/91-1792 és 1807-ben látták el eredeti feladatukat. A Várkerület a királyi palota és az országgyülés közelsége miatt, a 18. században kedvelt foúri lakóhellyé vált. Az Úri utca és az azzal párhuzamosan futó utcák, a kis terek (a Dísz tér, a Bécsi kapu tér) által határolt épülettömbökben a legjelentösebb föúri családok alakították ki palotáikat. A Batthyány-palota (ma Dísz tér 3. szám alatt) helyén a 15. században Filippo di Stephano Scolari (1369-1426) háza állt, amelynek romjaiból 1689-ben építtetett fel egy emeletes lakóházat Werlein István (†1695). Ezt 1743-ban gróf Batthyány Lajos (1696-1765) nádor és öccse, herceg Batthyány Károly (1698-1772) tábornagy vásárolta meg, majd 1744-1746 között megbízásukból átalakították, 1748ban kétemeletesre bővítették a palotát, ahol 1751. augusztus 8-án a Budára látogató Mária Terézia királynőt fogadták. A szemközti palota (ma Dísz tér 15. szám alatt) helyén a 14. században Hédervári Miklós (1309-1330) föispán, mellette báró Drágffy Bertalan (1447-1501) főpohárnok, erdélyi vajda háza állt. Előbbit 1504-ben Bakócz Tamás (1442-1521) esztergomi érsek birtokában találjuk. Az 1723-ban összeépített épületekből 1760-ban Anton de la Motte Jolly des Aulnois (†1800) alezredes alakíttatott palotát. A közeli Tárnok utca 9-13. szám alatt herceg Esterházy Pál (16351713) nádor palotája állt, amelyet 1817-ben herceg Esterházy Miklós (1765-1833) tábornagy jelentősen bővített és átalakított. A Táncsics Mihály utca 7. szám alatt álló palotát az 1743. évi adásvételt követően, 1750-1769 között építtette ki gróf Erdődy III. György (1676-1759) országbíró, koronaör. A palotát 1912-ben Hatvany-Deutsch József (1858-1913) cukorgyáros vásárolta meg, és még halála előtt, 1913-ban alakíttatta át saját igényei szerint. A közeli Táncsics Mihály utca 19-23. szám alatti palotát 1805-ben gróf Almásy Antal (1765-1834) császári-királyi kamarás, helytartói tanácsos alakíttatta ki; majd 1869-ben gróf Zichy Jenő (1837-1906) országgyülési képviselő építtette át. A Várlejtők közelében - a Várhely nyugati oldalán - egyetlen jelentős, kerttel övezett föúri palota épült: 1853-1856 között gróf Karácsonyi Guido Lajos (1817-1885) politikus megbízásából, a mai Krisztina körút 55. szám alatt, Kalmárffy Ignác (1753-1823) városi bíró, országgyülési követ 1790-ből származó palotája helyén. (A palotát 1938-ban lebontották. $)^{25}$

A 18. századi pozsonyi és budai fơúri magánpaloták jellemzően a zártsorú beépítés utcavonalra elhelyezett épületének egy vagy több, zárt belsőudvaros változatát követték, ahol az épületbe történő megérkezéshez az utcai épületszárny földszintjén

\footnotetext{
${ }^{25}$ Lechner 1924. 190-191; Lestyán 1940. 75-82.
} 
nyíló kapun és kapualjon kellett keresztülhajtani. A palota belső térkompozíciót meghatározó eleme a kocsibehajtó kapualj volt, amely a hozzá kapcsolódó, a társasági termeket és a lakosztályokat feltáró lépcsőházzal legtöbbször reprezentatív együttest alkotott (1. típus). A belső udvar mélyén, a földszinten általában kiszolgáló és üzemi rendeltetések (istállók, konyhák, szolgaszállások stb.) voltak megtalálhatóak. Ennél az elhelyezkedésnél és építészeti elrendezésnél a palotához kapcsolódó kert kialakítására általában nagyon kevés hely volt, így csak kisebb belső kert vagy az uralkodói székhely erődítéseihez alkalmazkodó, a terepviszonyokat is kihasználó - terasz-, illetve teraszos - kert létesülhetett a korszakban. Nagyobb kertek kialakítására, elsősorban a városfalakon kívüli szabad területeken nyílt lehetőség, amelynek a palota építészeti elrendezésére gyakorolt hatásaként értéklehető, hogy az udvarok egyik - jellemzően az utcához vagy ellenkezőleg, a kerthez kapcsolódó - oldalukon nyitottá váltak (2-3. típus).

Pest város központjában, a Vármegyeháza (ma Városház utca 7. szám alatt) szomszédságában, a jelentős forgalmú hatvani út mellett, a ferences templommal szemben (ma Kossuth Lajos utca 4. szám alatt) 1730-1735 között gróf Grassalkovich Antal (1694-1771) koronaőr, királyi személynök építtetett palotát. (1887-ben lebontották.) Pest főterén, a piarista rendház szomszédságában báró Péterffy János királyi ítélőtáblai ülnök 1755-1756 között építtetett kisebb palotát (ma Piarista utca 2. szám alatt). A városközponttól délkeletre, a városfal közelében (ma Károlyi Mihály utca 16. szám alatt) áll gróf Barkóczy V. Ferenc (1710-1765) esztergomi érsek, helytartótanácsi

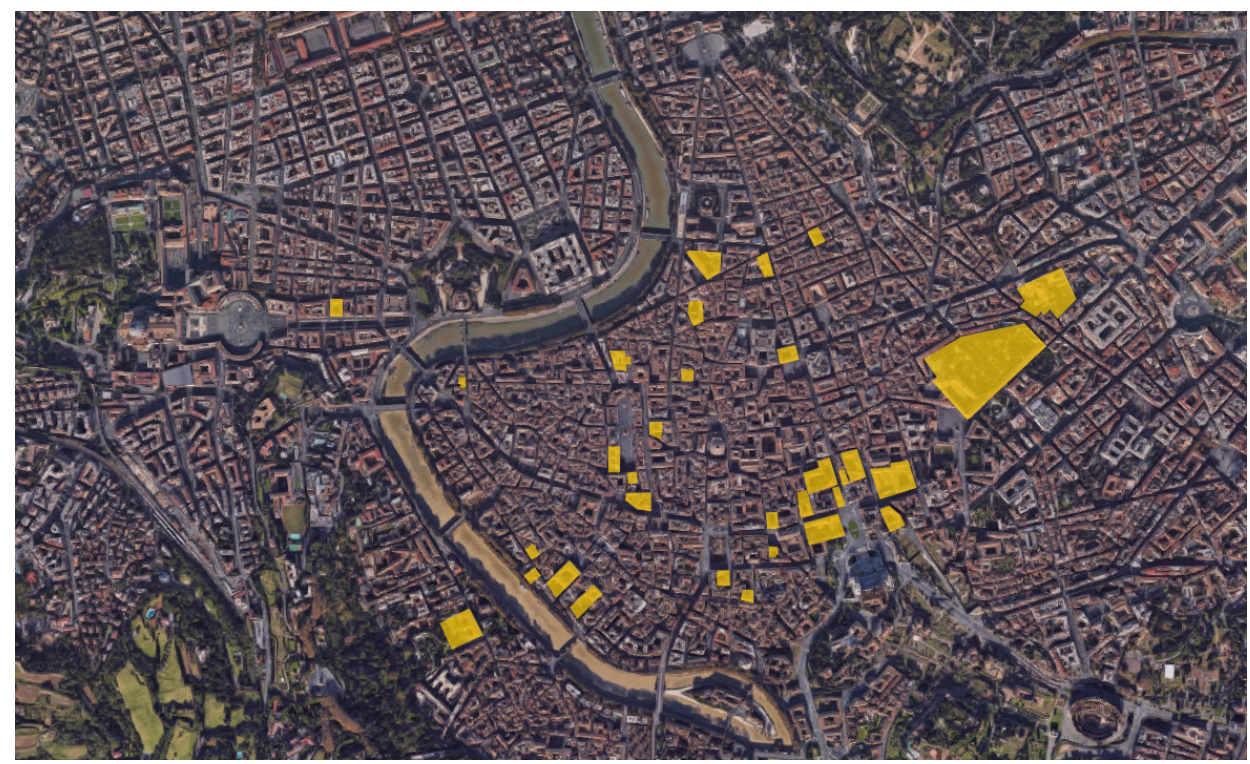

6. a) ábra. A jelentősebb római paloták diszpozíciója 

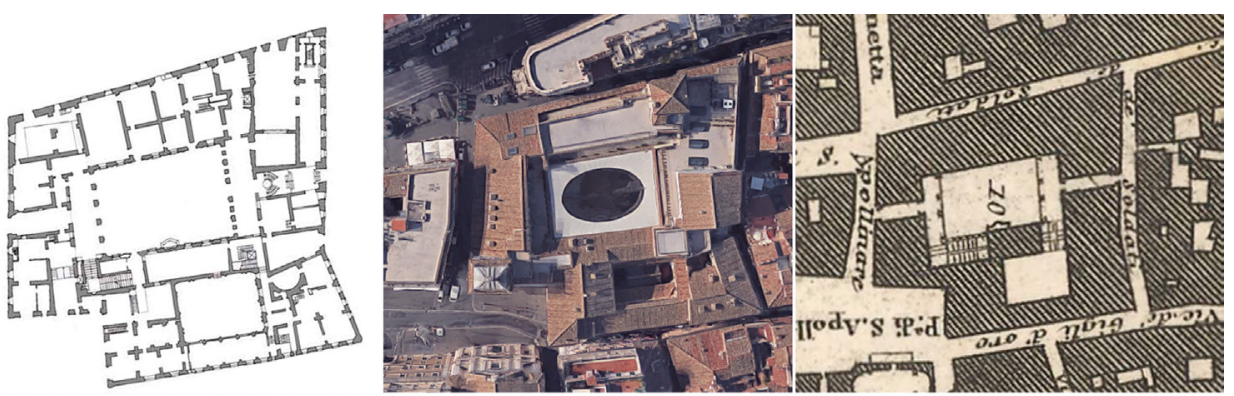

ROMA, VIA DI SAN APOLLINARE 46., PALAZZO RIARIO-ALTEMPS, 1480
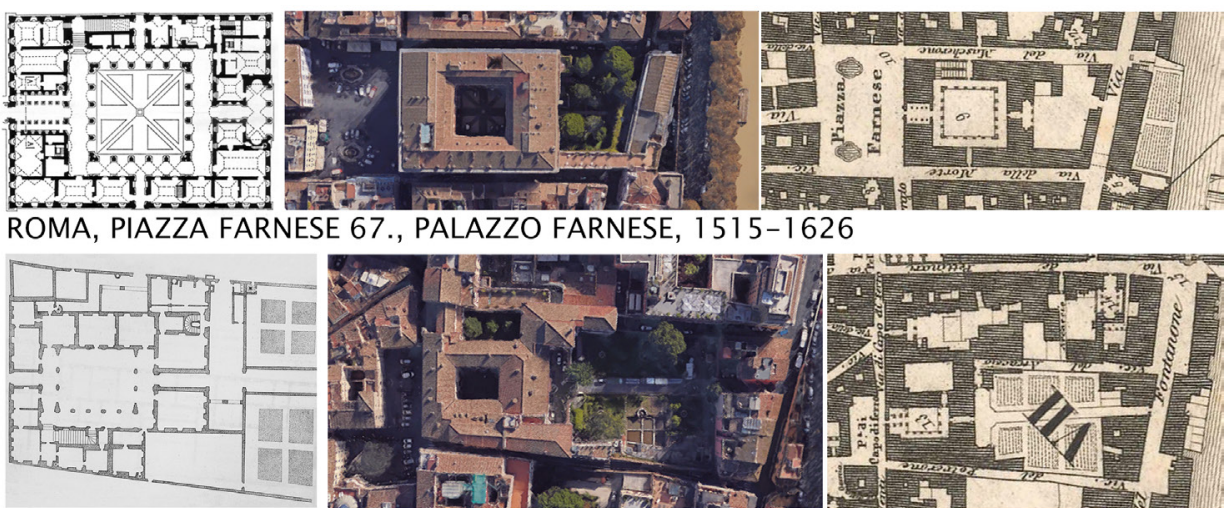

ROMA, PIAZZA CAPO DI FERRO 13., PALAZZO SPADA, 1548-1632
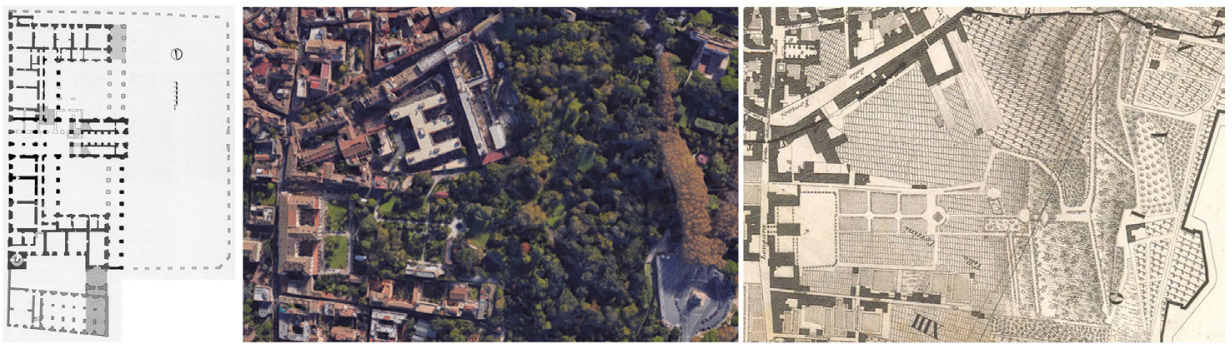

ROMA, VIA DELLA LUNGARA 10., PALAZZO CORSINI, 1511-1758
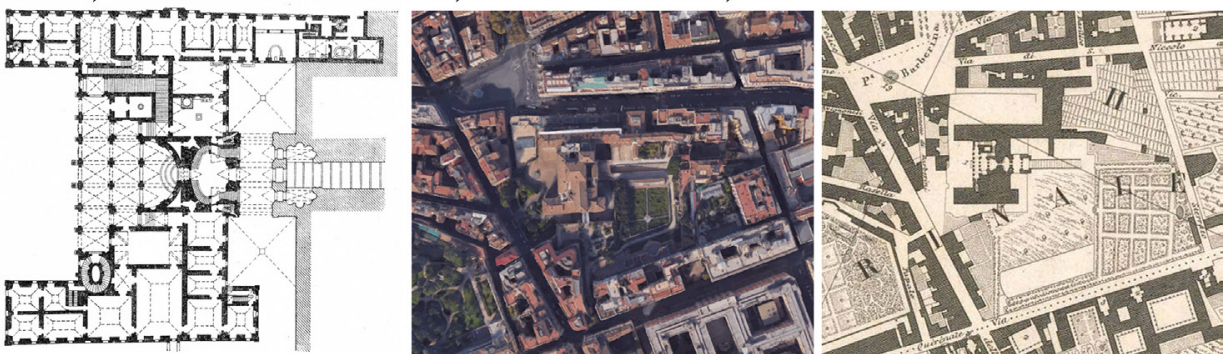

ROMA, VIA DELLE QUATTRO FONTANE 13., PALAZZO BARBERINI-COLONNA, 1625-1633

6. b) ábra. A jelentősebb római paloták diszpozíciója és típusai, változatokkal 
tanácsos palotája és kertje, amelyet 1759-1768 között kibővíttetett. 1769-től gróf Károlyi Antal (1732-1791) táborszernagy, föispán tulajdona lett az épület, amelyet 1928-ig a Károlyi család többször átépíttetett. Ebben a palotában élt gróf Károlyi Mihály (1875-1955), Magyarország miniszterelnöke, illetve első köztársasági elnöke. A városfalon kívül, annak közelében az Országút mellett (ma Múzeum körút 14-16. szám alatt) báró Klobusiczky Ferenc (1707-1760) kalocsai érsek 1751-1760 között építtetett palotát és kertet, amelyet később gróf Batthyány József (1727-1799) esztergomi érsek vásárolt meg. ${ }^{26} \mathrm{Az} 1836$. évi 37. törvénycikk biztosította Pesten a Magyar Nemzeti Múzeum felépítéséhez szükséges összeget. Az építkezés 1837 és 1847 között folyt, amelynek során, 1838-ban a palota és kert együttesét lebontották. Az új múzeumépület nagyteremében ülésezett az 1848-as népképviseleti országgyülés felső háza. Később, 1861-ben és 1865-66-ban a képviselőház, 1867-től 1902-ig, a mai Országház megépüléséig, pedig a felsőház müködött itt. 1865-től 1902-ig a szomszédos Főherceg Sándor utcában (a mai Bródy Sándor $u$. 8. sz.) a Magyar Országgyűlés Képviselőháza nagytermében zajlottak az alsóházi ülések.

Pest reformkori városfejlődése során - az 1786-tól több ütemben lebontott városfal és feltöltött városárok külső és belső oldalán, részben az újonnan szabályozott telektömbökben - is jelentős fóúri palotaépítkezés folyt. A belvárosban a gróf Teleki család birtokolt több épületet. 1871 óta gróf Teleki Gáza (1844-1913) politikus, belügyminiszter házassága révén került birtokába, a ma József nádor tér 7. szám alatt álló palota, amelyet 1833-ban a görög származású gyapotkereskedö, Murat Panajot (1785-1843) bővíttetett kétemeletessé egy 1791-ben épített lakóház felhasználásával. Ebben a palotában született gróf Teleki Pál (1879-1941), a Magyar Királyság későbbi miniszterelnöke, aki korábban külügy-, valamint vallás- és közoktatásügyi miniszterként is müködött. 1873 óta a mai Szervita tér északi oldalán (Szervita tér 8-10. szám alatt) álló palotát 1836-ban bővítették, a mellette álló kisebb házat 1838ban bérházzá alakították át. 1862-ben gróf Teleki Sándor (1829-1875) és öccse, Gyula (1833-1893) háromemeletesre bővítette a palotabérházat. (1949-ben lebontották.) Nem messze innen, a hatvani út közelében gróf Szapáry Antal (1802-1883) fórendiházi háznagy a ma Szép utca 6. szám alatt 1817-ben építtetett palotát. 18271829 között gróf Cziráky Antal Mózes (1772-1852) országbíró építtetett palotát a közelben, a ma Szép utca 2. szám alatt. 1859-ben az épületbe a Pesti Kaszinó költözött. Az új piactér (ma Erzsébet tér) környékén Festetics Antal (1764-1853) császári és királyi kamarás 1826-1830 között palotabérházat építtetett a ma Zrínyi utca 8-10. szám alatt. Ennek közelében, 1830-1833 között gróf Marczibányi Márton (17851835) országgyülési követ építtette fel nagyméretű palotáját a ma Zrínyi utca 13. szám alatt. 1837-ben készült el gróf Szapáry Péterné (1774-1824) csillagkeresztes palotahölgy palotája (ma Mérleg utca 11. szám alatt), amely 1875-ben gróf Karátsonyi Jenőné (1865-1937) birtoka lett. 1808-1825 között a pesti Duna-partot a Szépítő Bizottmány tervszerü munkával alakította, hogy az árulerakásra alkalmasabb legyen, továbbá megtörtént az Ács tér (ma Széchenyi István tér) parkosítása is. A tér keleti

\footnotetext{
${ }^{26}$ Berlász 1990. 149-165.
} 
oldalára emelt házak közül az egyiket (ma Széchenyi István tér 5-6. szám alatt) gróf Nákó János (1814-1875) vette meg és 1861-1869 között nagyszabású palotává bővíttette. (A palotát 1903-ban bontották le.) A szomszédságában (ma Széchenyi István tér 4. szám alatt) álló házat 1836-ban vette meg herceg Ferdinand von SachsenCoburg-Gotha (1785-1851) és felesége, Koháry Antónia (1797-1862) hercegnő. Fiuk, Ferdinánd (1816-1885) 1836. január 1-jén feleségül vette II. Mária de Bragança (1819-1853) portugál királynőt, akitől született leszármazottai voltak a Portugál Királyság uralkodói 1910-ig, a köztársaság kikiáltásáig. A család a pesti Duna-parton álló épületet 1874-ben alakíttatta át. (A palotát 1905-1909 között lebontották.) A hajdani városfalakon kívül gróf Károlyi György (1802-1877) főispánnak - a reformkor egyik legnagyobb formátumú alakjának és mecénásának - a palotája 1859-1868 között (a ma Erkel Ferenc utca 19. szám alatt), palotabérháza pedig 1875-1876 között (a ma Erkel Ferenc utca 15. szám alatt) épült fel. ${ }^{27}$

A 19. század második felében, a Magyar Nemzeti Múzeum új épülete és a Képviselőház közelében közel 30 főnemesi palota épült fel. A legjelentősebbek között tartható számon a ma a Pollack Mihály tér 10. szám alatt gróf Festetics György (1815-1883) főispán, a király személye körüli miniszter, belső titkos tanácsos, koronaőr, királyi föudvarmester palotája és kertje, amely 1862-1867 között épült. A mai Pollack Mihály tér 3. szám alatt gróf Károlyi Alajos (1825-1889) diplomata, nagykövet palotája, kertje és bérháza 1863-1865 között létesült. A közelben gróf Károlyi

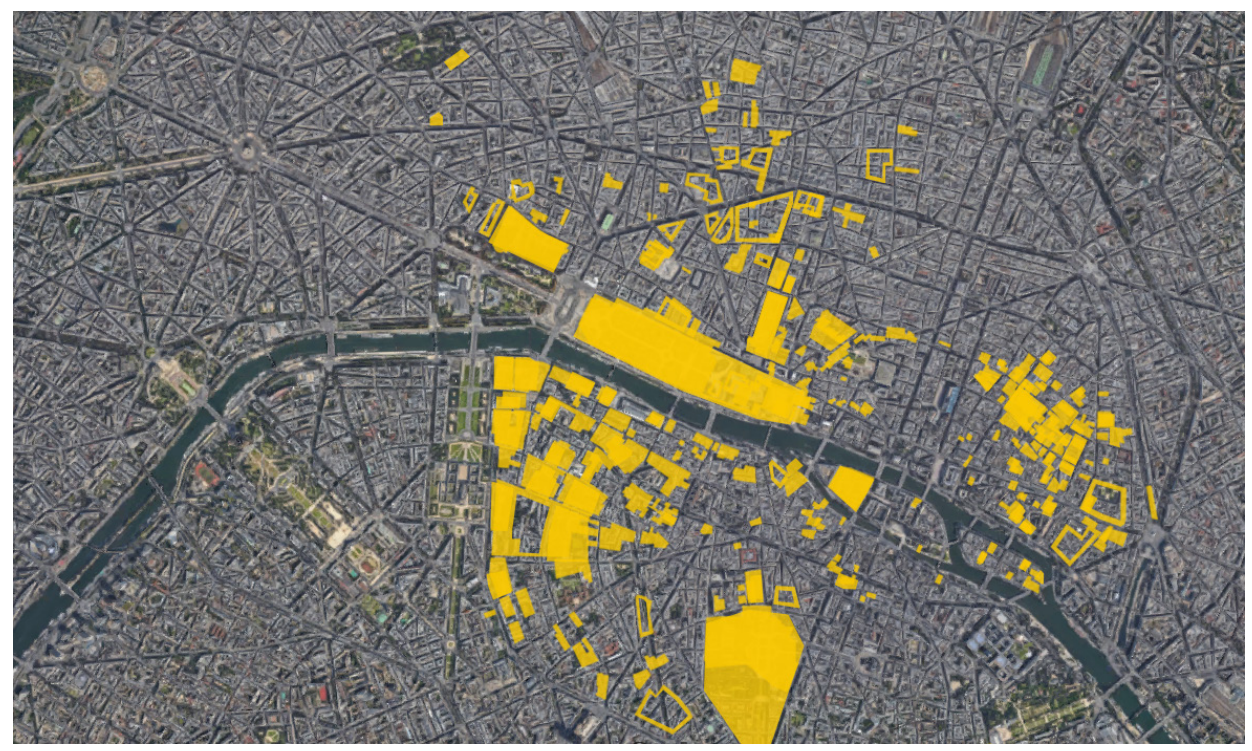

7. a) ábra. A párizsi paloták diszpozíciója

${ }^{27}$ Benedek; Pogány 1959. 242-246. 

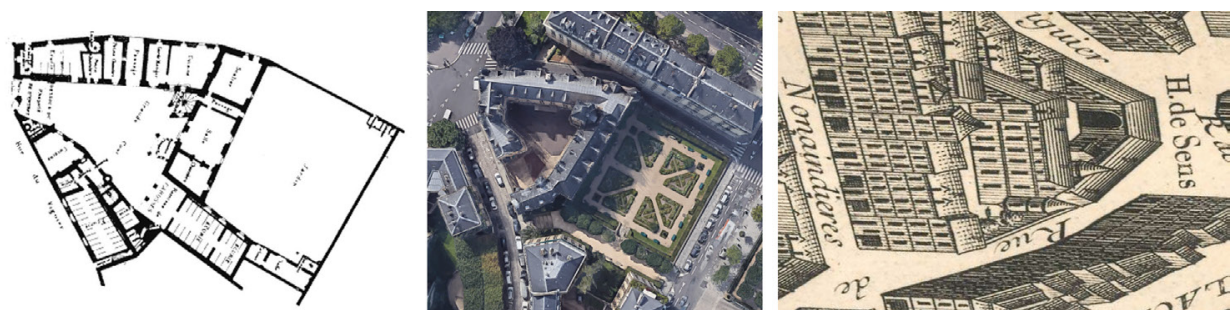

PARIS, RUE DE FIGUIER 1., HOTEL DE SENS, 1474-1606
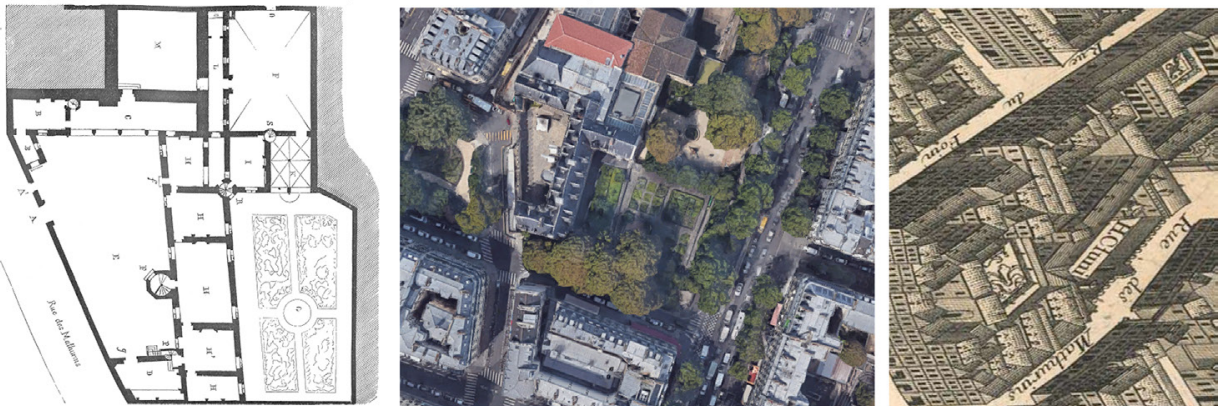

PARIS, PLACE PAUL PLAINLEVÉ 6., HOTEL DE CLUNY, 1480
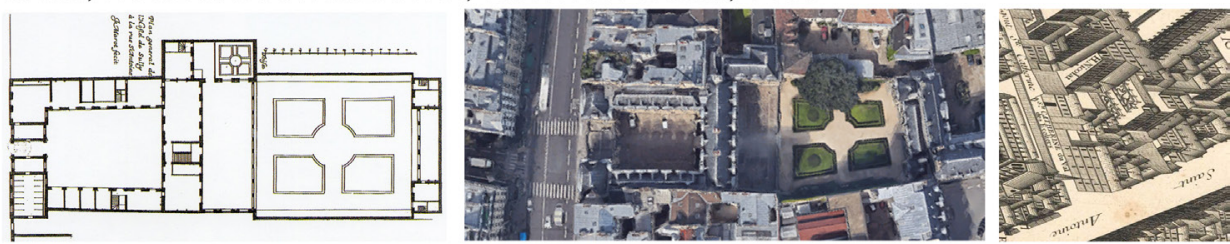

PARIS, RUE SAINT-ANTOINE 62., HOTEL DE SULLY, 1634
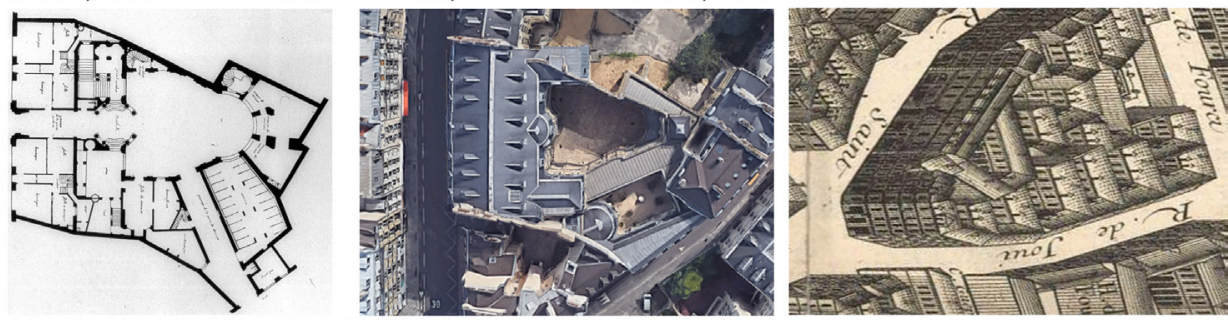

PARIS, RUE FRANCOIS MIRON 68., HOTEL BEAUVAIS, 1654-1657

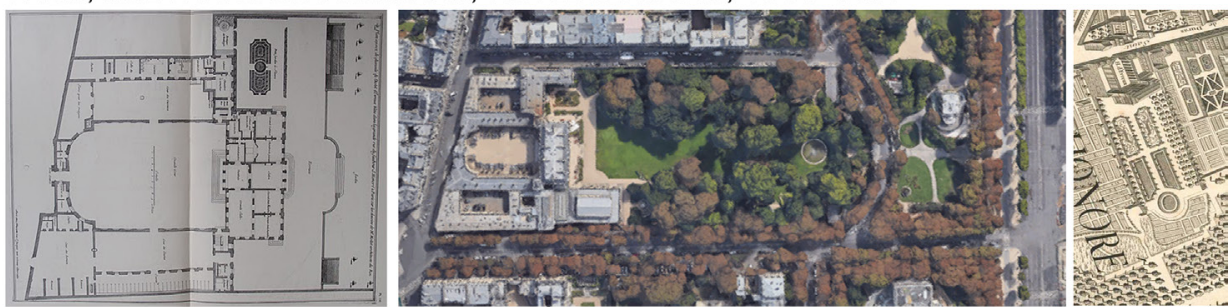

PARIS, RUE FAUBOURG SAINT-HONORÉ 55., HOTEL D' EVREUX, 1718-1722

7. b) ábra. A párizsi paloták diszpozíciója és típusainak változatai 

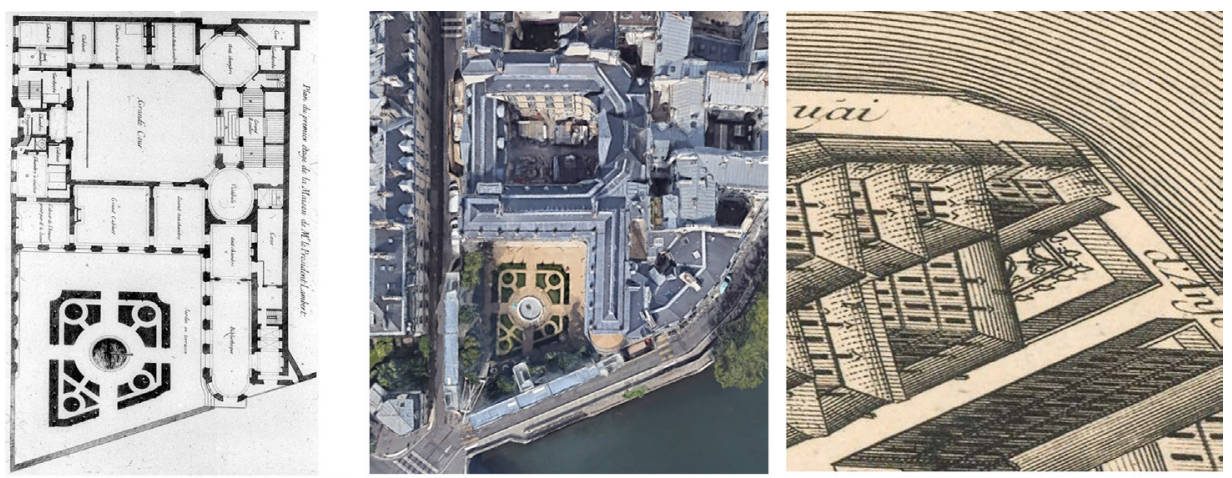

PARIS, RUE SAINT-LOUIS EN L'ILE 5., HOTEL LAMBERT, 1640-1656
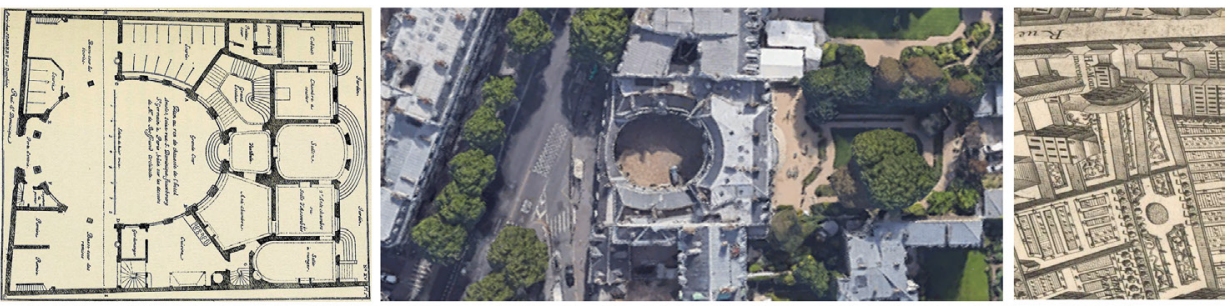

PARIS, RUE SAINT-DOMINIQUE 1., HOTEL D' AMELOT DE GOURNAY, 1710-1713
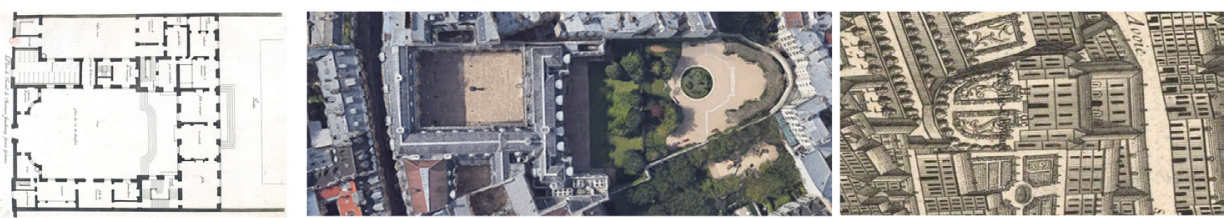

PARIS, RUE DU TEMPLE 71., HOTEL DE SAINT-AIGNAN, 1644-1650
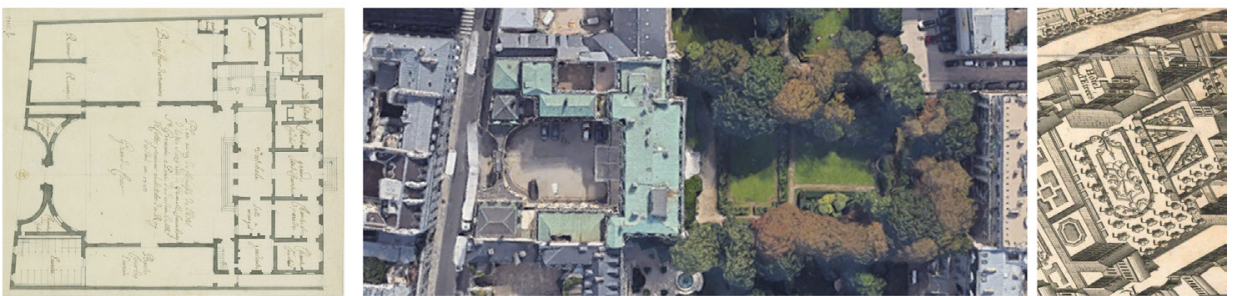

PARIS, RUE DE GRENELLE 79., HOTEL D’ ESTRÉES, 1711-1713
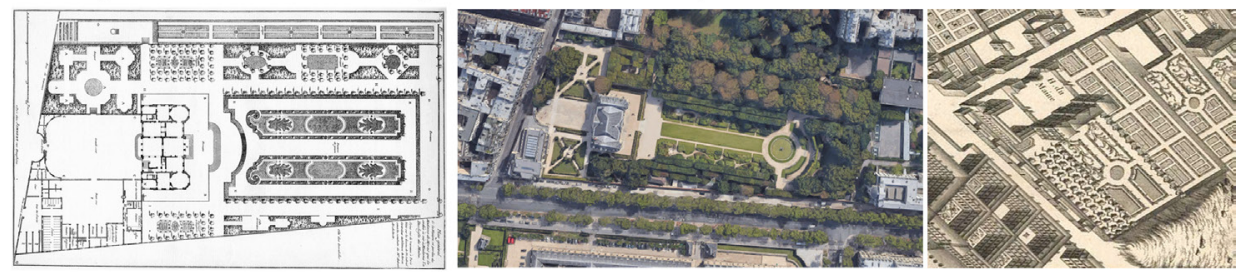

PARIS, RUE DE VARENNE 79., HOTEL DE BIRON, 1728-1730

7. b) ábra. A párizsi paloták diszpozíciója és típusainak változatai (folytatás) 
Geraldine (1836-1915) - gróf Pálffy Pál (1827-1866) föispán, császári és királyi kapitány felsége - a ma az Ötpacsirta utca 4. szám alatt álló palotáját és kertjét, 1867-1869 között építtette fel. 1865-1871 között gróf Esterházy Ferenc (18591909) építtetett palotát a ma Pollack Mihály tér 8. szám alatt. A Múzeum u. 11. szám alatt álló palotabérházat 1869-1871 között építik fel gróf Károlyi István (1797-1881) föispán számára. A Bródy Sándor u. 9. szám alatt gróf Keglevich István (1840-1905) képviselő 1871-ben építtette fel palotáját. Gróf Degenfeld-Schomburg Imre (18101883), a Tiszántúli Református Egyházkerület főgondnoka, képviselő 1872-1874 között, a ma Bródy Sándor utca 14. szám alatt építtetett palotabérházat. A ma Bródy Sándor u. 4. szám alatt gróf Dessewffy Miklós (1829-1893) palotája 1874-1877 között, a Múzeum u. 17. szám alatt, gróf Károlyi István (1845-1907) országgyülési képviselő palotája 1881-ben; a ma Szabó Ervin tér 1. szám alatt, gróf Wenckheim Frigyes (1842-1912) palotája pedig 1886-1889 között épült fel. A Reviczky u. 3. szám alatt áll az 1893-1896-ban gróf Pejacsevich Tivadar (1855-1928) horvátszlavón-dalmát bán számára épített palota. Végül a Múzeum $u$. 5. szám alatt gróf Hadik-Barkóczy Endre (1868-1927) főrendiházi képviselő 1896-ban építtette fel a palotáját. $^{28}$

A budai Duna-part palotasora között volt megtalálható (ma Lánchíd utca 10. szám alatt) gróf Széchenyi István (1791-1860) közlekedési miniszter, a „legnagyobb magyar" 1860-ban még kivitelezés alatt lévő palotája, amely halálával fia, gróf Széchenyi Béla (1837-1918) koronaőr tulajdonába került. A palotát 1871-1873 között háromszintes épületté bővítették. Közeli szomszédjában (ma Lánchíd utca 4. szám alatt) 1869-ben vásárolt házat báró Lipthay Béla (1827-1899) főispán, országgyülési képviselö, aki 1872-1874 között új palotabérházat építtetett. Előbbi épület 1945 májusában, az utóbbi 1949-ben semmisült meg. A Bem rakpart 6-7. szám alatt gróf Andrássy Gyula (1823-1890) miniszterelnök megrendelésére 1878-1880 között épült fel palotabérháza. Az épület északi oldalán lévő három házat (ma Bem rakpart 8. szám alatt) 1890-ben dr. Emmer Kornél (1845-1910) kúriai bíró, országgyülési képviselö, igazságügyi miniszter vásárolta meg, amelyek helyére 1885-1886 között palotabérházat építtetett.

Pest-Buda városfejlesztésének ügyét 1867 után gróf Andrássy Gyula (1823-1890) miniszterelnök vette kézbe, a fejlődő Magyarországnak egy erős, modern fővárost kívánt teremteni. 1868. május 17-én pest-budai vegyes bizottságot hívott össze, ahol megfogalmazták a város fejlődése és szépítése iránti igényeket, többek között a Pest központját és a Városerdőt (Városligetet) összekötő új, reprezentatív útvonal kiépítését. 1871 folyamán megtörténtek a kisajátítások, és felkérték a kor neves építészeit, hogy készítsék el az útvonal egyes épületeinek tervvázlatait. 1872 januárjában megalakult a Sugárúti építővállalat, augusztus 1-jén elkezdődött az első régi ház elbontása, az év végére pedig megindult néhány új ház alapozása is. Az első látványos tömb, az Oktogont közrefogó négy bérház 1873-ban készült el. 1876-ig befejezték az útvonal teljes müszaki előkészítését és kivitelezését. 1876. augusztus 20-án ünne-

\footnotetext{
${ }^{28}$ Hatolkay 1960. 153-161; M. Szücs; Bende 2000. 12; Pogány 1959. 280-283.
} 
pélyes keretek között adták át. Az Andrássy úton az utolsó telket 1886-ban építették be. A történelmi fönemesség palotaépítkezései azonban viszonylag kis számban jelentek meg itt. Gróf Pejacsevich Pál (1813-1907) politikus, förendiházi tag palotabérháza (ma Andrássy út 46. szám alatt) 1878-ban épült. A herceg Koháry-Coburg család 1880-as évek elején építtetett palotája az Andrássy út 94-96. szám alatt áll. A gróf Andrássy család palotája 1882-ben az Andrássy út Oktogonhoz közeli részén (ma Andrássy út 59. szám alatt) épült. Pallavicini Sándor (1853-1933) őrgróf, nagykövetségi attasé 1885-ben elkészült palotája (ma az Andrássy út 98. szám alatt) a sugárút Kodály Körönd utáni szakaszának egyik legreprezentatívabb épülete. Az Andrássy út közvetlen szomszédságában (ma Teréz körút 11-13.) 1884-ben épült fel gróf Batthyány Géza (1838-1900) alispán palotabérháza. Az Andrássy úti palotaépítkezésekben inkább az új arisztokrácia képviseltette magát nagyobb számban. Ezt példázza az Andrássy út 4. szám alatti palotabérház, amelyet báró Harkányi Frigyes

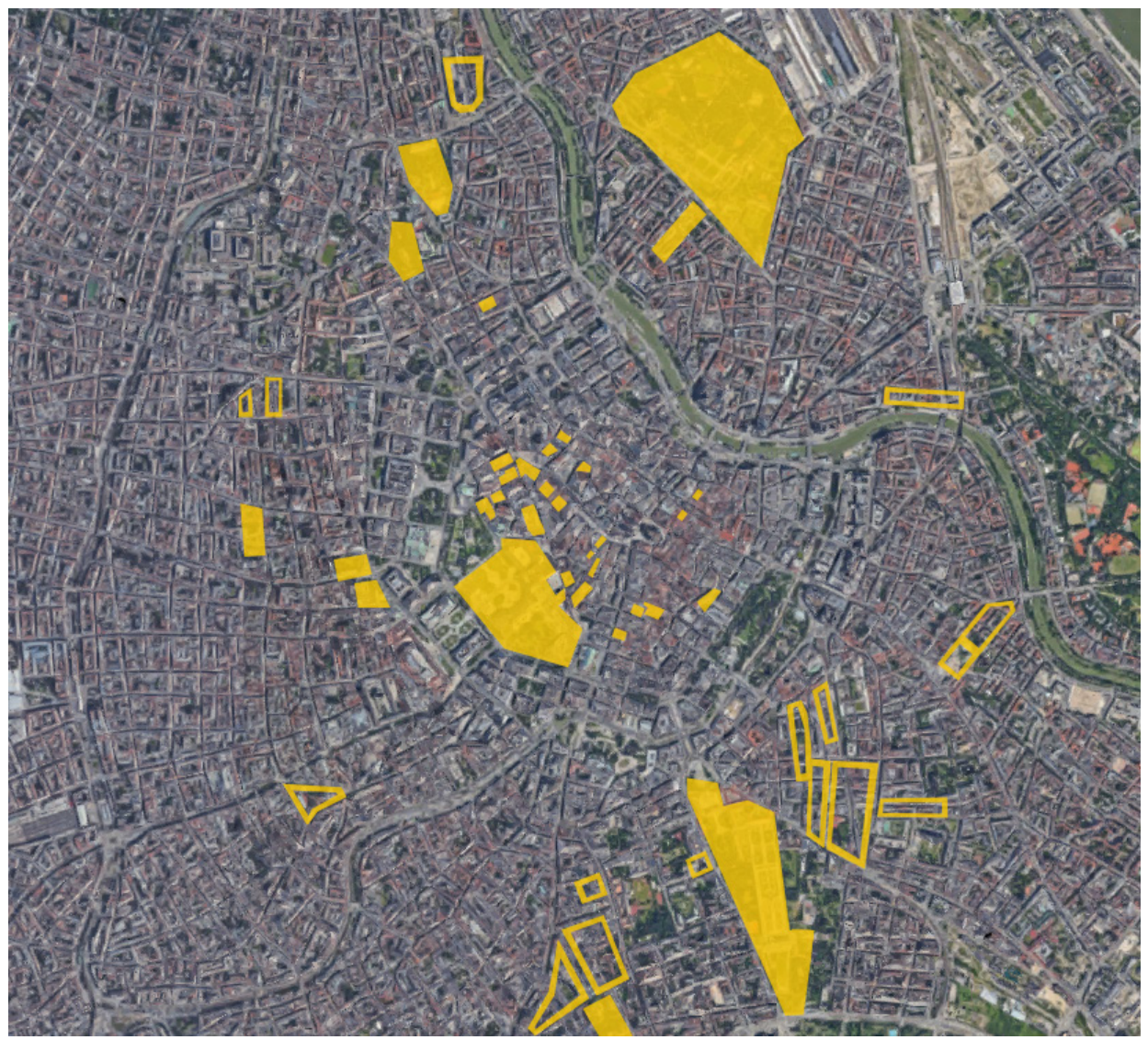

8. a) ábra. A jelentősebb bécsi paloták diszpozíciója 

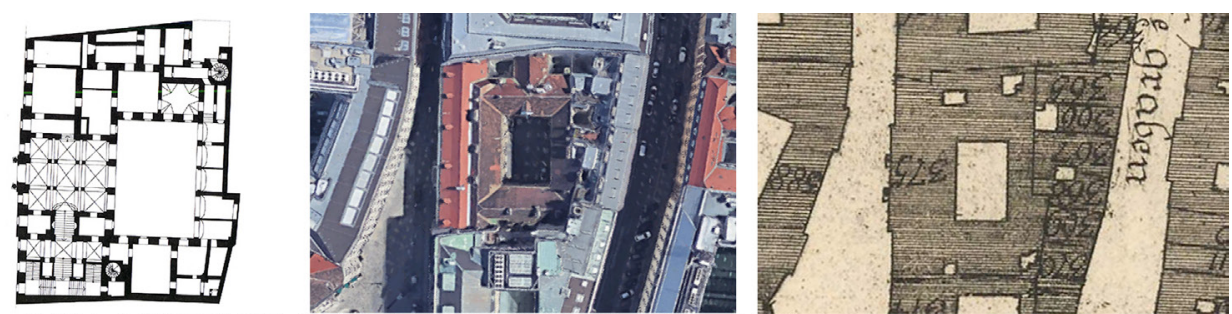

WIEN, RENNGASSE 4., PALAIS SCHÖNBORN, 1699-1706
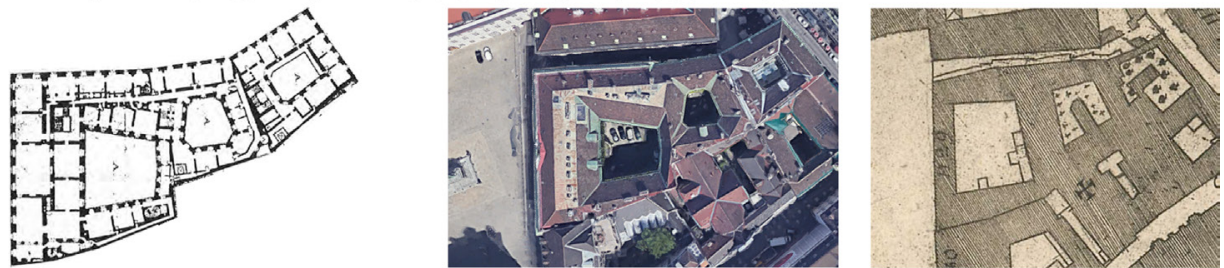

WIEN, JOSEFPLATZ 5., PALAIS PALLAVICINI, 1782-1850
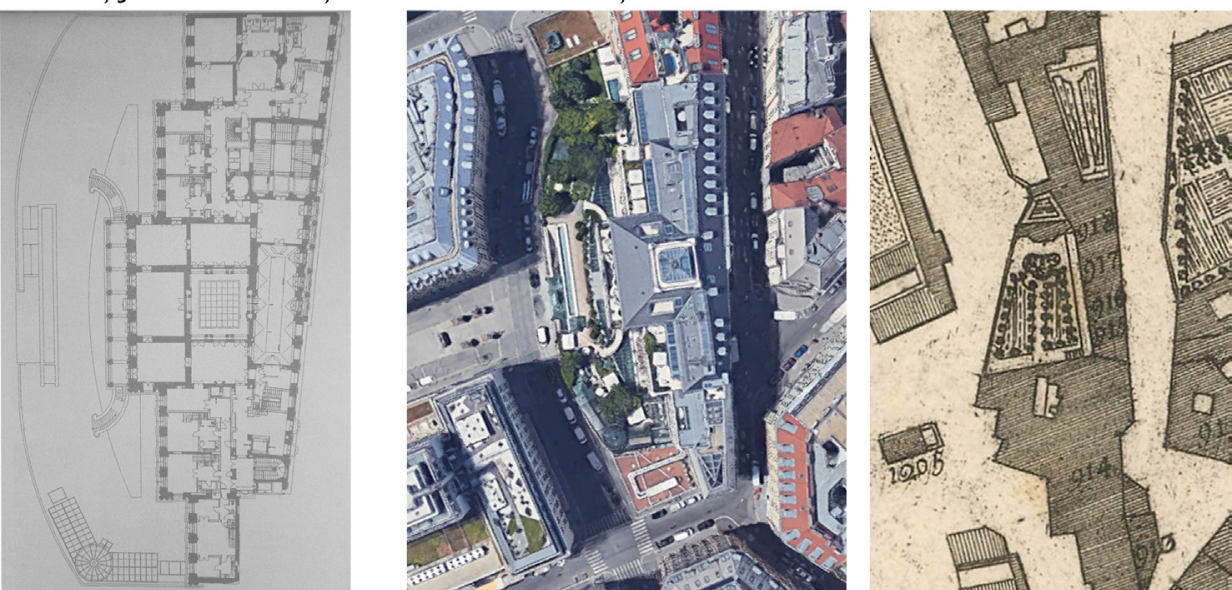

WIEN, COBURGBASTEI 4., PALAIS COBURG, 1839-1845
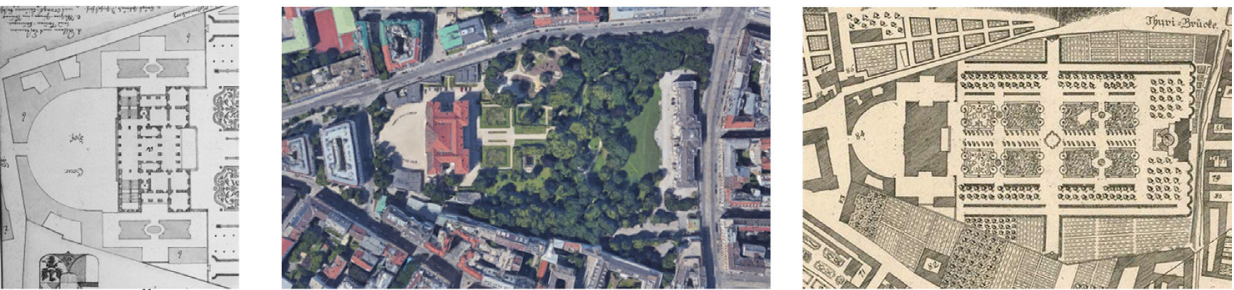

WIEN, FÜRSTENGASSE 1., PALAIS LIECHTENSTEIN, 1692-1872

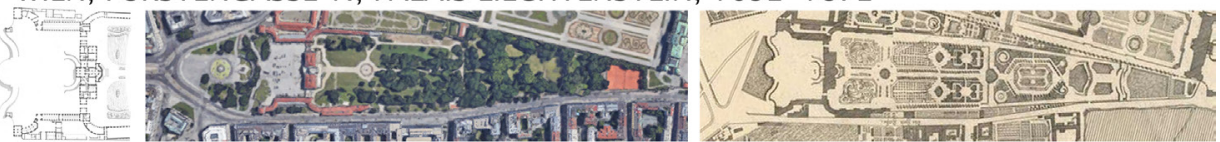
WIEN, PRINZ EUGEN STRASSE 9., PALAIS SCHWARZENBERG, 1697-1752

8. b) ábra. A jelentősebb bécsi paloták diszpozíciója és típusai, változatokkal 

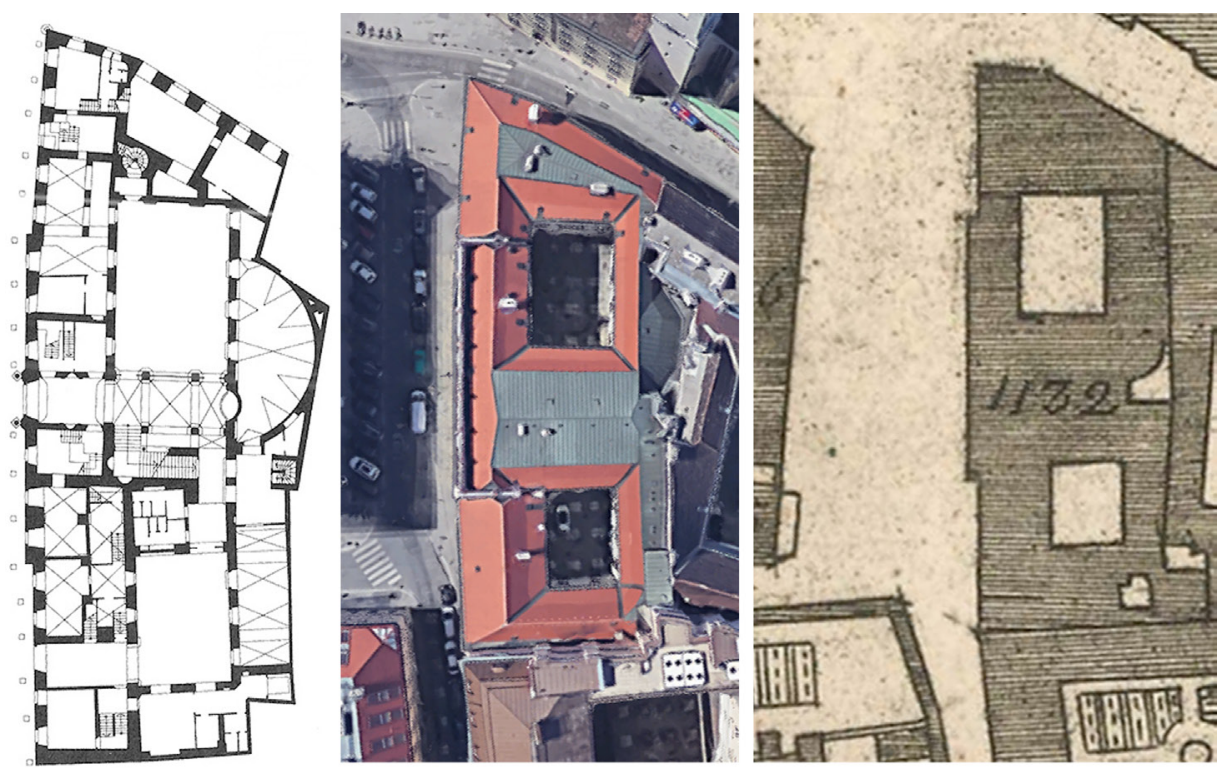

WIEN, LOBKOWITZPLATZ 2., PALAIS LOBKOWITZ, 1709-1711

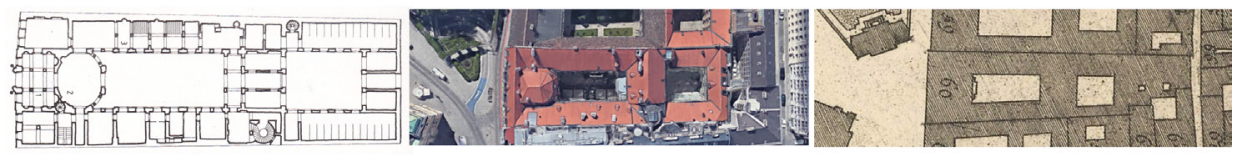

WIEN, FREYUNG 4., PALAIS DAUN-KINSKY, 1713-1719
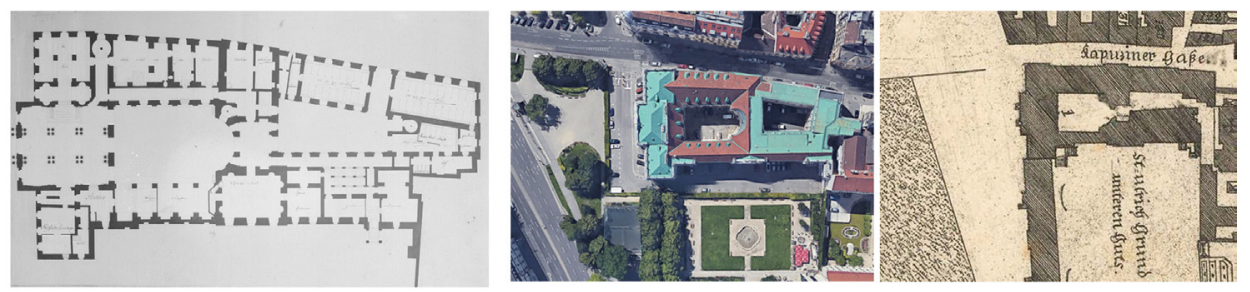

WIEN, MUSEUMSTRASSE 7., TRAUTSON PALAIS, 1712-1760

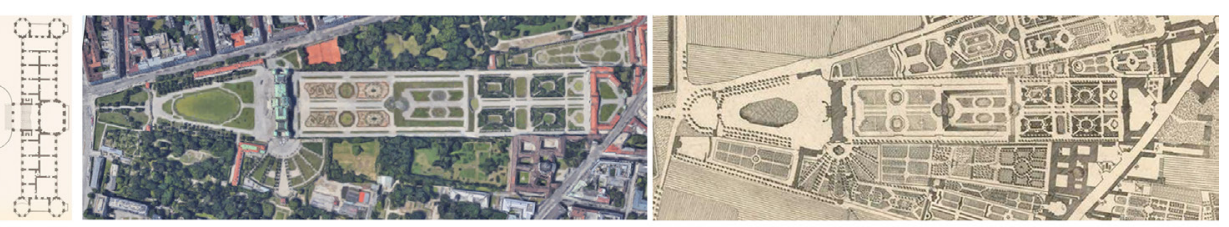

WIEN, PRINZ EUGEN STRASSE 27., BELEVEDERE, 1697-1716

8. b) ábra. A jelentősebb bécsi paloták diszpozíciója és típusai, változatokkal (folytatás) 
(1826-1919) országgyülési képviselö, förendiházi tag számára 1882-1884 között építettek fel. 1884-1886 között épült az Andrássy út 3. szám alatt álló palotabérház Saxlehner András (1815-1889) posztókereskedő megbízásából. A dúsgazdag és európai hírü mügyüjtő, báró Herzog Mór Lipót (1869-1934) huszárszázados 1885-ben építtetett az Andrássy út 93. szám alatt fényüző palotát. Az Andrássy út 52. szám alatti palota 1886-ra készült el Haggenmacher Henrik (1827-1917), a sörfözésben, a malomiparban egyaránt érdekelt, svájci származású magyar nagyiparos számára.

A 19. században a fơuri magánpaloták településen belüli elhelyezésének újszerü vonása a városi zöldfelület, közparkok közelébe, illetve forgalmi központok (rakpartok, sugárutak) köré vagy annak mentén történő reprezentatív telepítés volt. Az épületek rendeltetéselemeinek építészeti kialakítása annak ellenére is korszerüsödött, hogy az alapvető udvaros elrendezések változatai megmaradtak. A paloták belső tereiben centrális térkompozíció jelent meg, a reprezentatív társasági terek a társadalmi érintkezés változó szokásai szerint specializálódtak, funkcionálisan differenciálódtak, és jellemzően a palota első emeletén vagy ritkábban a földszintjén monumentális teremcsoportot alkottak. Hazánkban a 19. század első harmadától megjelenő palotabérház (6. típus) a városi - pest-budai, majd budapesti - fóúri magánépítészet egyedi és különleges fajtáját képviselte. Ebben két olyan épületfajta kapcsolódott össze, amelyek jelentősen különböző társadalmi rétegek igényeit szolgálták ki differenciált diszpozícióval és térstruktúrával: az arisztokráciáét, az őket kiszolgáló szolganépét, valamint a polgárság különböző rétegeiét. A palotabérház típusainak elterjedése a kiegyezés kori fővárosban jellemző, Nyugat-Európában - például a föúri magánépítészet számára sok tekintetben mintaadó Bécsben - nem volt olyan elterjedt ez a kettős épülettípus, mint a magyar fỏvárosban. ${ }^{29}$ A palotabérház elrendezése jellemzően a belső, zártudvaros formát követte, a két (a palota és a bérház) épület egymás mellé helyezésével és kapcsolódó, illetve átjárható udvarok kialakításával. Különleges és egyedi megoldásnak számított ennél a típusnál, amikor a palota és a bérház között kert húzódott (4. ábra).

A föúri palota mint épületfajta az arisztokrácia, illetve a fönemesség magánépítészetében kifejezetten a városhoz kötődő lakóhely volt, minden korszakban a fényüző reprezentációs társasági termek, visszafogott lakóterek és nagy kiterjedésü kiszolgáló terek együtteseként jelent meg az építtető társadalmi réteg sajátos életmódjához igazodó megfelelőséggel. ${ }^{30} \mathrm{~A}$ palota téri elrendezésének előzményei már a 13-14. századi itáliai városokban megtalálhatók. A palota (palazzo) első típusalkotó példái Firenzében jelentek meg a 15. század közepén (4. ábra). A paloták hazánkban is mintaadó változatait a 16-17. században Rómában, a 17-18. században pedig elsősorban Párizsban (hôtel particulier, palais) és Bécsben (Stadtpalais, Gartenpalais) érlelték ki. A kertekkel létesített föúri paloták különlegesen reprezentatív példái Drezdában és Prágában jelentek meg a bemutatott korszakban.

\footnotetext{
${ }^{29}$ Váczi 1990; Váczi 1992. 66-73.

${ }^{30}$ Váczi 2003.
} 
A toszkán vagy a római palota a középkori, majd az újkori uralkodói központ (Firenze: Palazzo Vecchio, Palazzo Pitti; Roma: Palazzo Venezia, Palazzo Quirinale) vagy egy-egy jelentős szakrális épületegyüttes, templom környezetében (Firenze: Cattedrale di Santa Maria del Fiore, Basilica di Santo Spirito, Chiesa di Santa Maria del Carmine; Roma: Il Gesù), a városközpont piacterein (Firenze: Piazza della Signoria, Piazza della Republica; Roma: Piazza Navona, Piazza Colonna) és legforgalmasabb utcáin (Firenze: Via del Corso, Via Cavour, Via del Proconsolo; Roma: Via del Corso) helyezkedett el (5-6. ábra). A palota telekadottságokhoz igazodó, gyakran szabálytalan négyszögü, kívül minden oldalról zárt, belül négyzetes központi udvarra nyíló tömbje évszázadokra meghatározta az épület alaptípusát. Ebben az udvart lakó- és kiszolgáló épületszárnyak határolták körbe, a legfontosabb, reprezentatív társasági termek (,piano nobile”) az emeletre kerültek, a tulajdonosi lakosztály itt horizontális vagy a földszinttel megosztva vertikális elrendezést mutatott. A foúri palota monumentalitásának biztosítása érdekében gyakori megoldás volt, hogy a palota több telek felhasználásával, azokon lévő korábbi épületek befoglalásával, összeépítésével, jelentős átalakítás révén épült fel. A telektömbökben elhelyezkedő egy-, kettő- vagy háromudvaros épületek több változata terjedt el: a telektömböt átfogó vagy azt részben, jellemzően a sarkokon elfoglaló, vagy magát az épülettömböt alkotó, minden homlokzata előtt utcákkal határolt paloták jöttek létre. E típusváltozatok a palota több homlokzattal

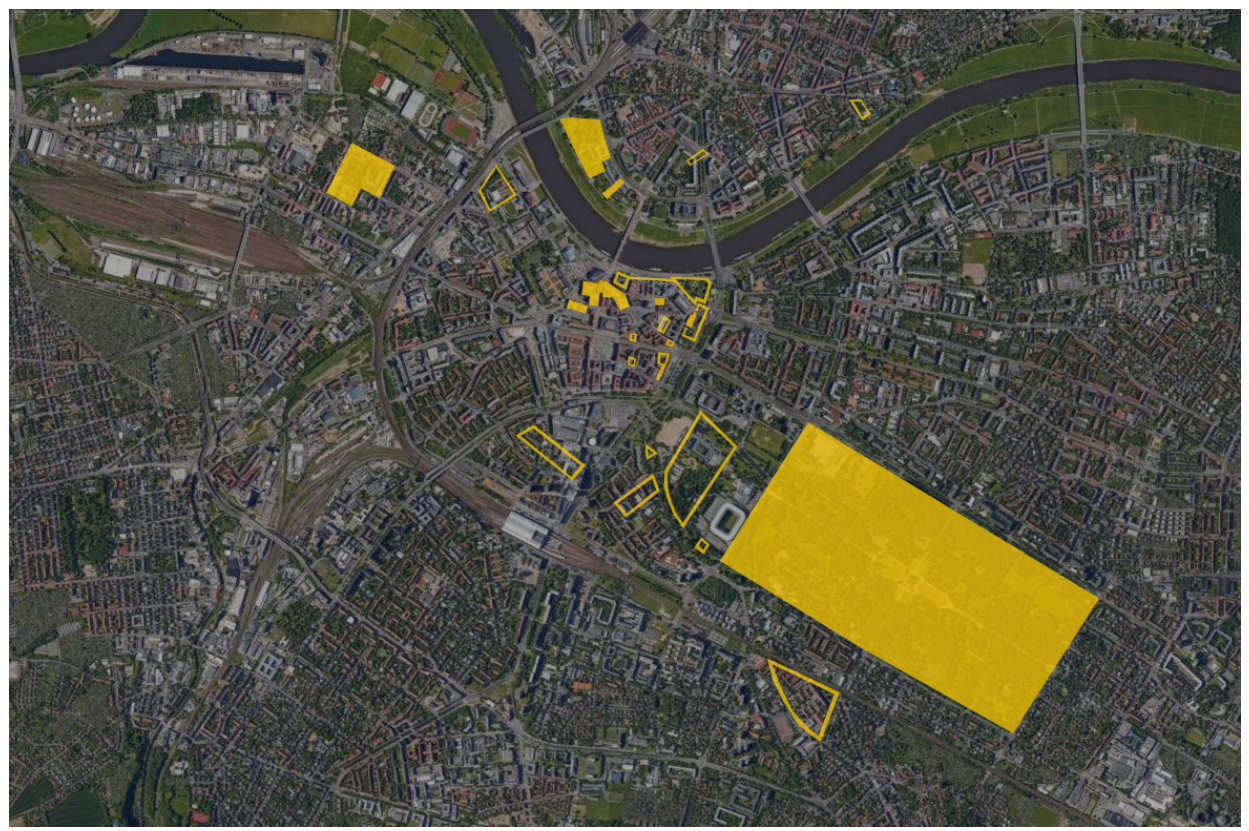

9. a) ábra. A jelentősebb drezdai paloták diszpozíciója 


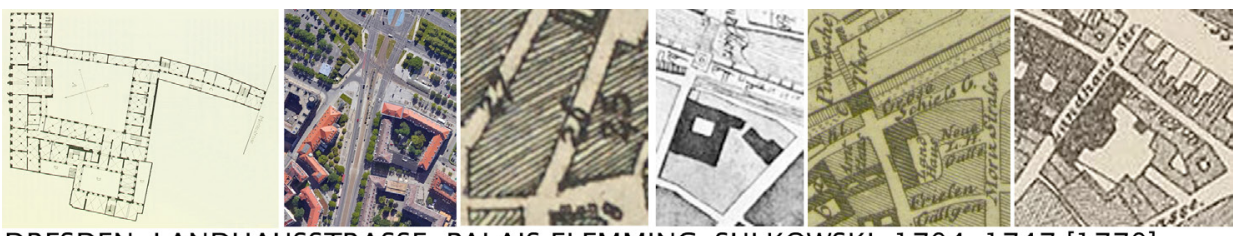

DRESDEN, LANDHAUSSTRASSE, PALAIS FLEMMING-SULKOWSKI, 1704-1747 [1770]

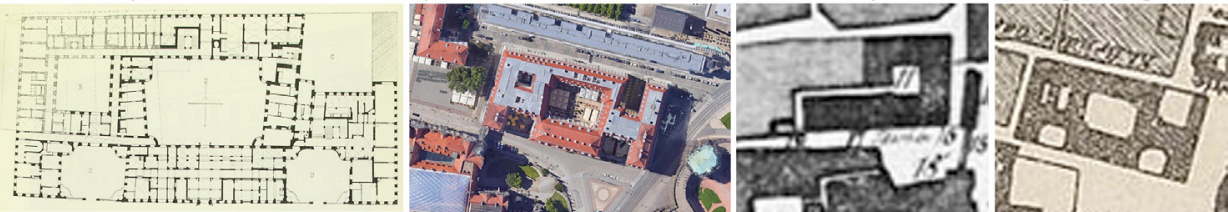

DRESDEN, TASCHENBERGPALAIS, 1705-1767, 1843-1934, [1945], 1992-1995

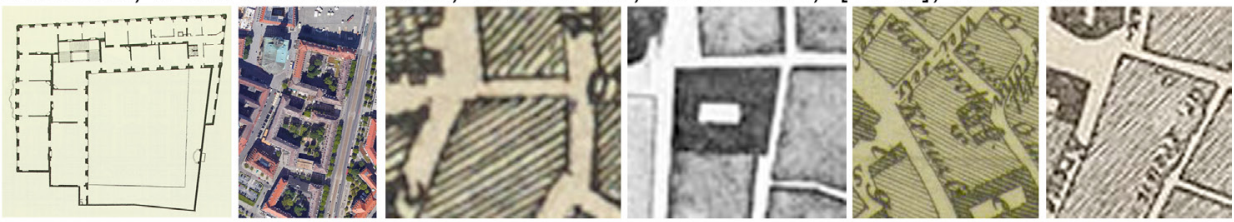

DRESDEN, KREUZGASSE, PALAIS VITZTHUM-RUTOWSKI, 1724-1753 [1 786]

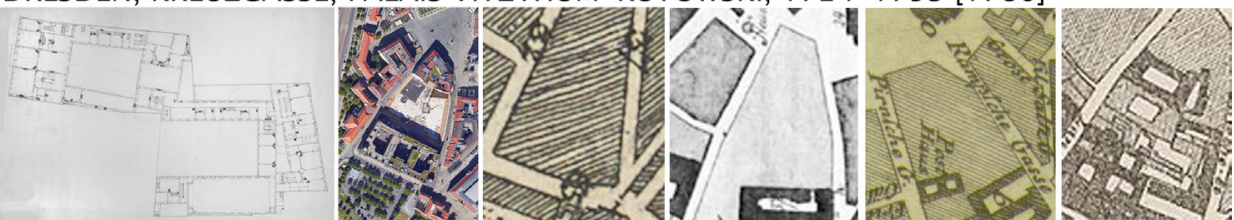

DRESDEN, LANDHAUSSTRASSE 11 ., PALAIS HOYM, 1739-1742, 1766 [1945]

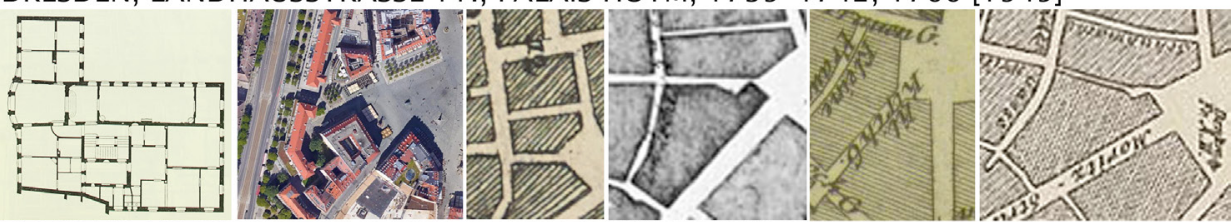

DRESDEN, WAISENHAUSSTRASSE 6., BOXBERG'SCHES PALAIS, 1752-1756 [1899]
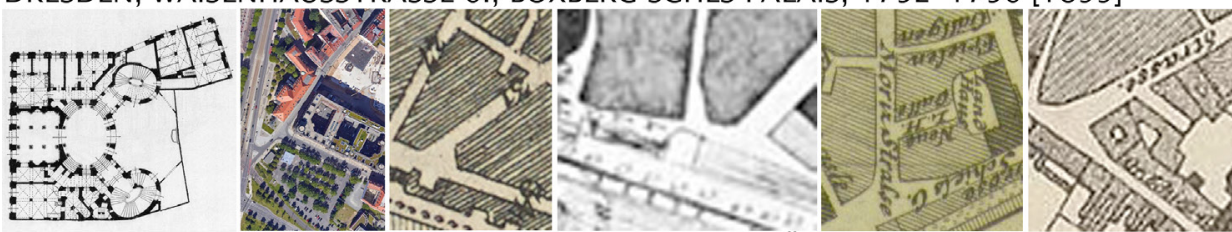

DRESDEN, MORITZSTRASSE 19., PALAIS VITZTHUM-SCHÖNBURG, $1756-1774$ [1 885]

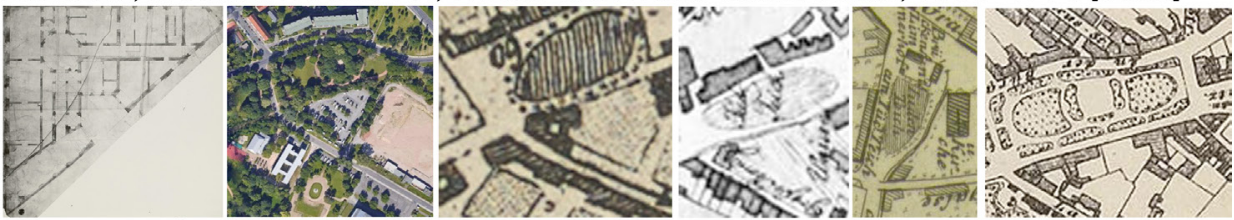

DRESDEN, BÜRGERWIESE 5-7., PALAIS KASKEL-OPPENHEIM, 1845-1874 [1945]

9. b) ábra. A jelentősebb drezdai paloták diszpozíciója és típusai, változatokkal 

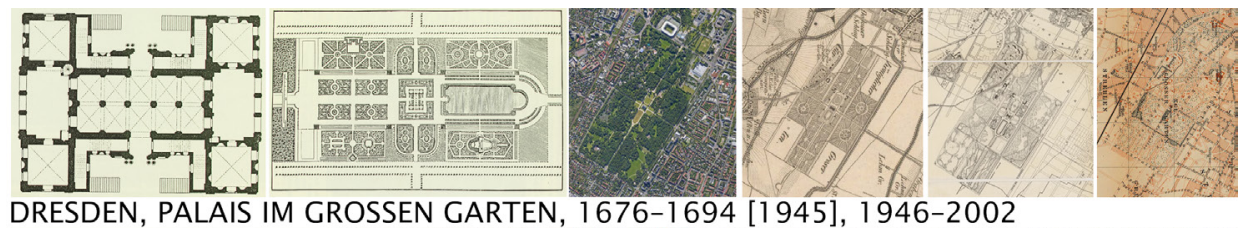

DRESDEN, PALAIS IM GROSSEN GARTEN, 1676-1694 [1945], 1946-2002

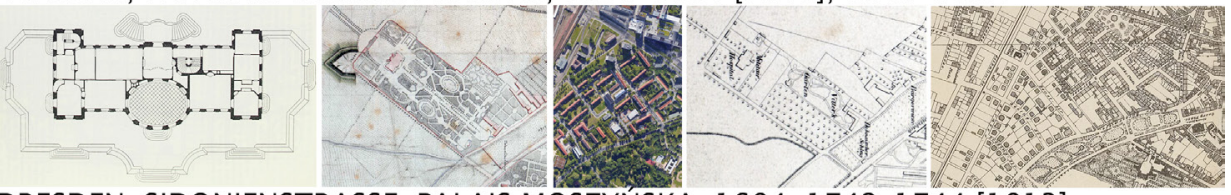

DRESDEN, SIDONIENSTRASSE, PALAIS MOSZYNSKA, 1684, 1742-1744 [1813]
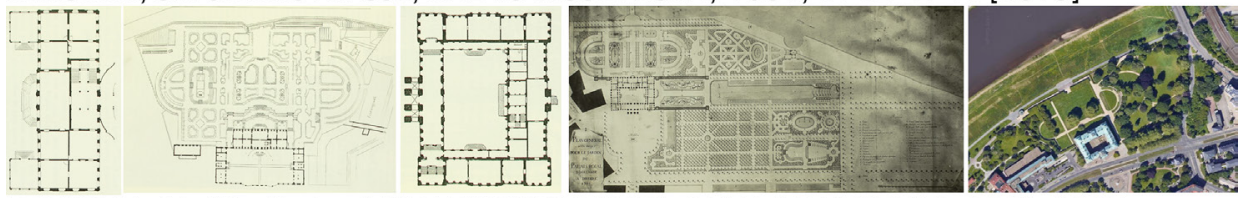

DRESDEN, [Holländisches] JAPANISCHES PALAIS, 1715-1744 [1945], 1951-1987

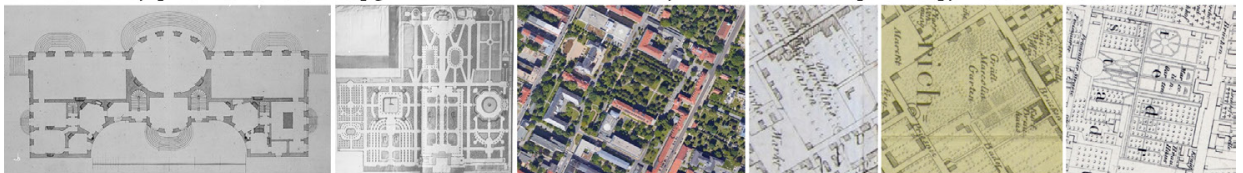

DRESDEN, FRIEDRICHSTADT, PALAIS BRÜHL-MARCOLINI, 1727-1778 [1 849]

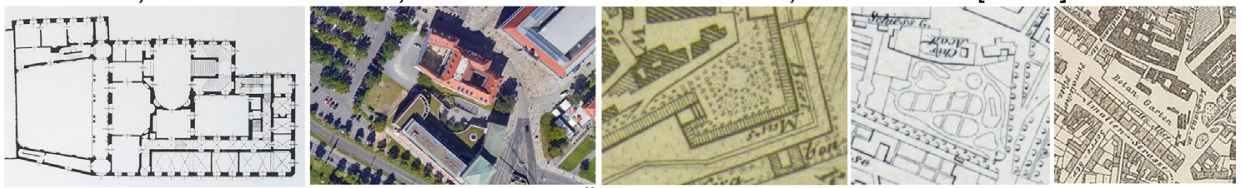

DRESDEN, TZSCHIRNERPLATZ 3-5., KURLÄNDERPALAIS, 1728-1774 [1945], 2006-2008

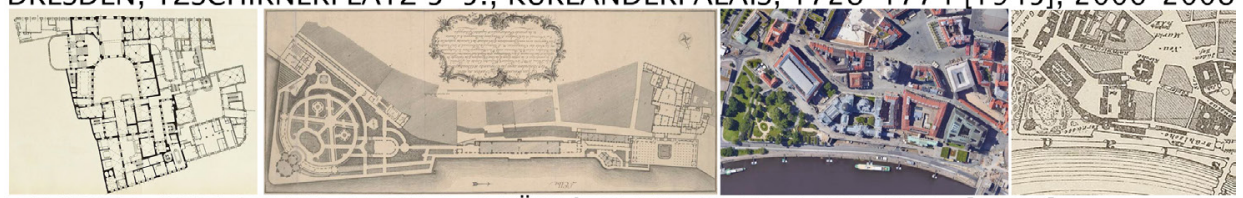

DRESDEN, AUGUSTUSSTRASSE 3., BRÜHL'SCHES PALAIS, 1737-1753 [1900]

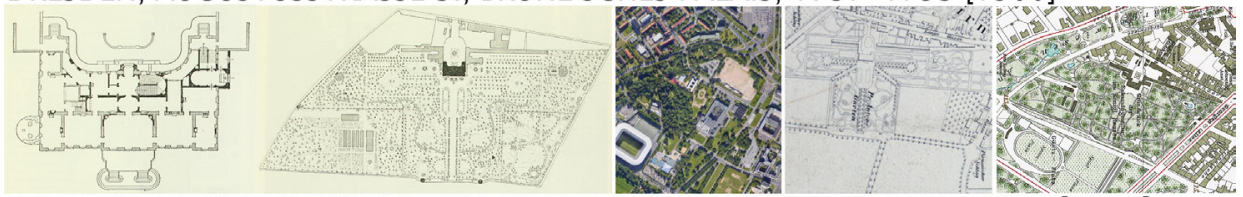

DRESDEN, LANGEN GASSE 24., PALAIS DER SEKUNDOGENITUR, 1764-1879 [1945]

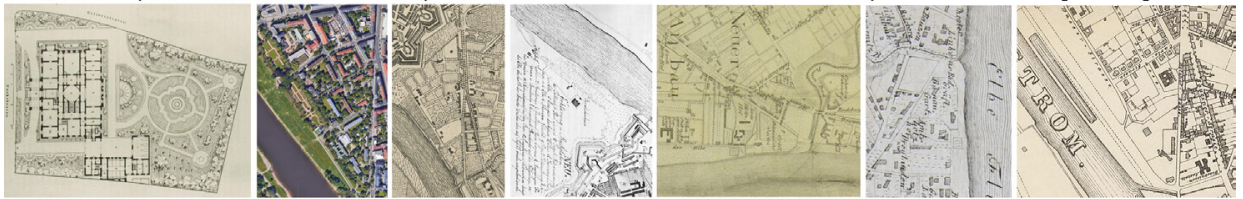

DRESDEN, PARKSTRASSE 7., PALAIS KAP-HERR, 1872-1912 [1945]

9. b) ábra. A jelentősebb drezdai paloták diszpozíciója és típusai, változatokkal (folytatás) 
történő kialakítását, a belső terek többirányú megnyitását tették lehetővé. A palotához esetenként kisebb, az épülettömbbe ékelődő kert kapcsolódott, amelyeket falakkal öveztek. ${ }^{31}$

Párizsban a középkori, majd újkori uralkodói és egyházi központok (Palais de la Cité, Louvre, Palais du Luxembourg, Église de Saint Germain des Près) vagy szálláshelyek (Les Invalides, Hôtel des Tournelles, Hôtel Saint-Pol) elsősorban a Szajna folyóhoz kötődően, annak közelében, a kikötők vagy az első folyami átkelő hidak által kitüntetett és stratégiailag is fontos helyre települtek. Az ezek köré csoportosuló (le quartier Richelieu, le faubourg Saint-Honoré, le Marais, le faubourg SaintGermain, le bourg Saint-Germain-des Près), később a Szajna-partot (Quai d'Orsay, Quai Anatole France, Quai Conti) is elfoglaló fơúri magánpaloták elrendezésének sajátos, francia típusát az épülettömbhöz kapcsolódó, az utca felé elhelyezkedő nyitott vagy jellemzőbben zárt fogadóudvar (előudvar) adja. ${ }^{32}$ Az udvart az utca felől és oldalt falakkal, kiszolgáló épületszárnyakkal övezték, és kettő vagy három részre (mellékudvarokra) tagolták. Utóbbiak a főbejárati kocsibehajtó mellett külön kapuval nyíltak az utcára. A fogadóudvar mögött, a telektömbök mélyén elhelyezkedő palotaépületek túloldalán kert kapott helyet, amelyet a palota földszintjéröl lehetett megközelíteni. Általában itt helyezkedtek el a reprezentatív társasági termek (,bel étage"), a tulajdonos és a vendégek lakosztálya jellemzően az emeleten volt (7. ábra).

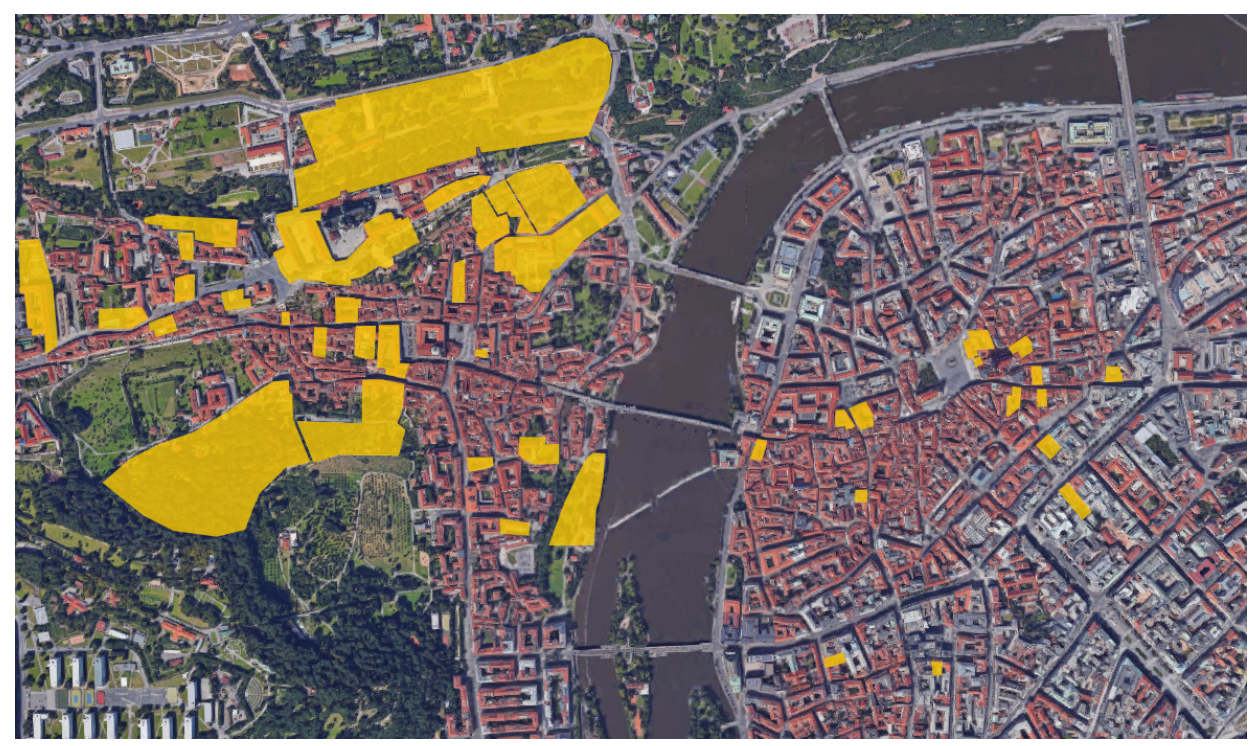

10. a) ábra. A jelentősebb prágai paloták diszpozíciója

${ }^{31}$ Profeti 1999; Benzi-Montanaro 2010; Cresti-Rendina 2007.

${ }^{32}$ http://paris-atlas-historique.fr/index.html (Utolsó megtekintés: 2020. 05. 07.) 

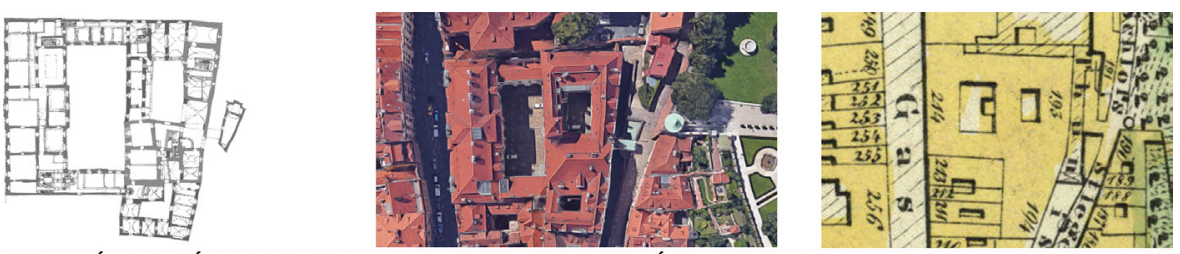

PRAHA, ZÁMECKÉ SCHODY 1., SLAVATOVSKY PALÁC, 1550-1847
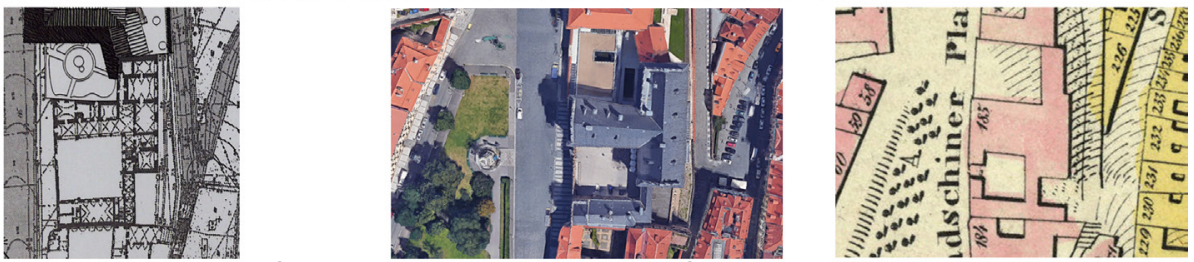

PRAHA, HRADCANSKÉ 2., SCHWARZENBERSKY PALÁC, 1545-1871
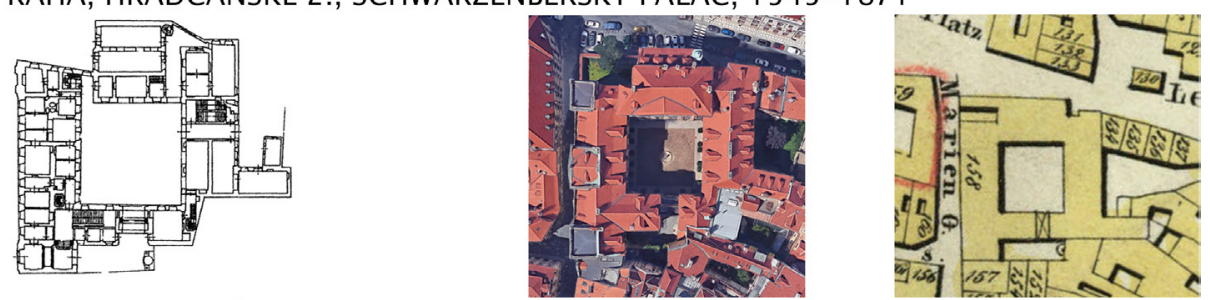

PRAHA, HRUSOVÁ 20., CALM-GALLASUV PALÁC, 1713-1729
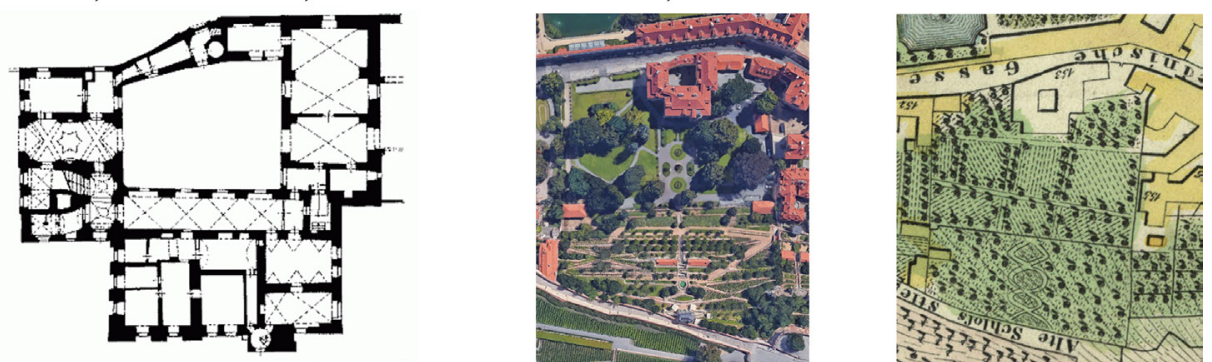

PRAHA, VALDSTEJNSKÁ 8., FÜRSTENBERSKY PALÁC, 1600-1860
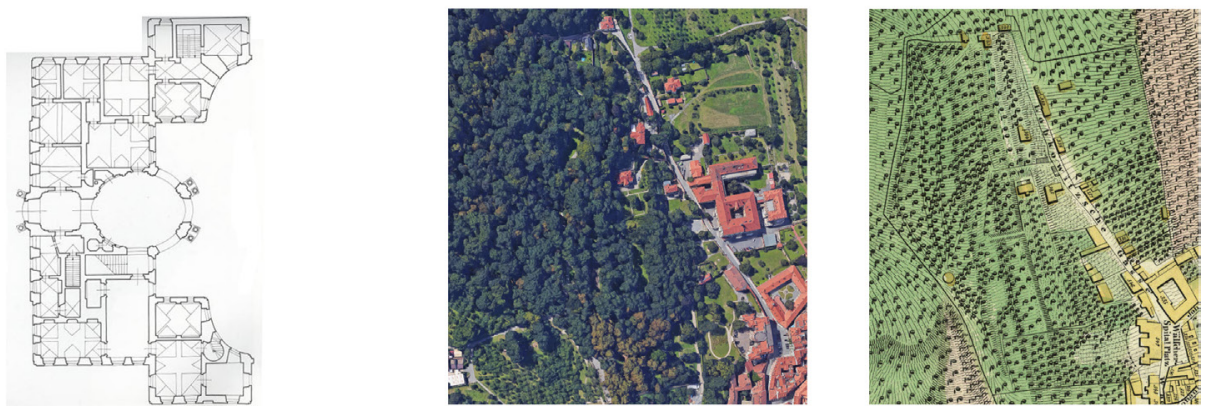

PRAHA, VLASSKÁ 19., LOBKOVICKY PALÁC, 1696-1790

10. b) ábra. A jelentősebb prágai paloták diszpozíciója és típusai, változatokkal 
A 17. század folyamán a paloták alaprajzi elrendezése is megváltozott, az épületek zártsága gyakran megszünt, helyette épületszárnyak fordultak a fogadóudvar és / vagy a kert felé, és az is elöfordult, hogy a palotakertben szabadon állva jelent meg. ${ }^{33}$

Bécsben, Drezdában a középkori uralkodói központ szintén a kikötők és az első folyami átkelö hidak által kitüntetett helyen, ugyanakkor a városerődítés hadászati, illetve védelmi szempontból és stratégiailag is fontos pontján, a városkapuk közelében települt (8-9. ábra). Az eköré csoportosuló és a városfalakon belül (Bécs: Renngasse, Fürstengasse; Drezda: Landhausstrasse, Waisenhausstrasse) elhelyezkedő, a 17. század végétől építtetett foúri magánpaloták elsősorban itáliai mintákat követtek a belső udvaros, zárt elrendezéssel. A városfalakon belül kertek kialakítására csak korlátozott lehetőség nyílt, a szükös belső kertek mellett a 18. század különleges megoldása volt az erődítések bástyáin elhelyezett teraszkertek telepítése (Bécs: Palais Coburg; Drezda: Kurlänerpalais, Brühl'schespalais), és ha az uralkodói rezidencia magaslatra épült (Prága: Hradčany), a várlejtőkön különleges és pompás teraszos kertek létesülhettek (Prága: Valdštejnská) (10. ábra).

Különösen nagy föúri kertek kialakítására a városfalakon kívül volt lehetőség (Párizs: Rue Monsieur le Prince, Rue du Louvre, Rue d'Aboukir, Boulevard Beaumarchais; Bécs: Burgring, Kärtner Ring; Pozsony: Hodžovo námestie, Námestie slobody, Špitálska). Bécsben, Drezdában e típust önálló névvel - Gartenpalais illették (1., 7-9. ábra), Párizsban az ilyen elhelyezésü palota leggyakrabban a maison de plaisance városi típusát jelentette. Drezda városfalain kívül a szász uralkodók által a 17. század második harmadától létesített, a pompás udvari ünnepségeknek vagy más alkalmakkor privát elvonulásnak helyet adó mulatókertben - Lustgarten álló paloták (Drezda: Palais im Grossen Garten, Palais der Secundogenitur; PrinzMax-Palais) egyaránt mutatták az itáliai és a francia hatásokat és váltak az uralkodói kegyben részesítettek, továbbá az udvari föurak számára követendő példákká (Drezda: Palais Moszyńska; Palais Brühl-Marcolini) ${ }^{34}$ (7-9. ábra).

Összefoglalva: Magyarországon is, valamint a hazai előképül szolgáló - példaként kiemelt - jelentős európai nagyvárosokban is egyaránt megtalálható volt a foúri lakóhelyek városi környezetben emelt palotáinak tipikus és jellegzetes építészeti kialakítása, amelyben az egy vagy több belső udvar, a zárt elö- vagy fogadóudvar, a falakkal lehatárolt belső kert és a szintén elkerített tágasabb park többféle elrendezési változattal, egyaránt alkalmazott építészeti megoldás volt. A palotatípusok legegyszerübb, Firenzétől Pest-Budáig elterjedt, nagyszámú megoldását a zárt belső udvar köré szervezett épületszárnyak diszpozíciója adta (1. típus). E típushoz belső kert is tartozhatott, az épületszárnyak több udvart is körbefoghattak. Kert kapcsolódása esetén az udvarok a kerti oldalukon meg is nyílhattak (2. típus). Közös jellemzőjük, hogy az épületbe történő megérkezéshez az úri fogatnak, később automobil-

\footnotetext{
${ }^{33}$ Blanc-Bonnemaison 2002; Naudin-Nicolay-Mazery 1999.

${ }^{34}$ Gurlitt 1903. 463-604.
} 
nak be- vagy át kellett hajtani az utcavonalon álló épületszárnyon, így annak a belső térkompozíciót meghatározó eleme a kocsibehajtó kapualj volt, amely a hozzákapcsolódó, a társasági termeket vagy a lakosztályokat feltáró lépcsőházzal legtöbbször reprezentatív együttest alkotott. Nem volt szükség viszont a fó épülettraktusba történő kocsibehajtásra a nyitott előudvaros (3. típus) és a Párizsban jellemző, majd onnan elterjedt, zárt fogadóudvaros diszpozíciónál (4. típus), ahol az utcavonalon álló kapu mögött egy tágas elö-, illetve fogadóudvar húzódott, amelyeket a kapu két oldalán kerítéssel vagy kiszolgáló rendeltetéseket befogadó épületszárnyakkal öveztek. E típusnál a fóépületbe gyalogosan lehetett belépni, az elöcsarnok már a földszinten biztosította a közösségi, nyilvános termek közvetlen, reprezentatív megközelítésének lehetőségét, így a társasági fö szint a palota földszintjén helyezkedett el a leggyakrabban, és jellemzően a főbejárat túloldalán kijárat nyílt az épülettömb belsejébe nyúló kertbe. A föúri magánépítészet különleges és ritka megoldását képviselte a kertjében vagy parkjában szabadon álló városi palota (5. típus), amely a 17. század végétől, a francia maison de plaissance mintájára, korábbi itáliai előképek nyomán jelent meg például Drezdában, Bécsben vagy Pozsonyban. Szintén különleges és újszerü diszpozíciós megoldás (6. típus) volt végül a két városi épületfajtát ötvözö, ún. palotabérház, amely a 19. század első harmadától jelent meg Bécsben és honosodott meg nagyobb számban Pest-Budán (11. ábra).

A lakóhely-építészetben a jellegzetes föúri életforma városi környezetben történő sajátos leképezése a palota elhelyezésében és építészeti elrendezésében is kimutatható, amelynek jellemző vonása az elsősorban világi hatalmi (illetve uralkodói) központ köré történő csoportosulás, így e központ köré koncentrálódó (centralizált) elhelyezés. A differenciált társadalmi helyzetből következő térbeli izolációt emellett a városfalakon kívüli elkülönült elhelyezés is biztosította, amelyet a városszerkezeti és topográfiai adottságokon (a városfalakon és az azokat körülvevő külső árkok és mezők gyürüin) túl természeti, táji elemek (különösen például folyó közelsége, hegyoldal jelenléte stb.) is befolyásoltak. A 18-19. században a föúri életforma változása, így a nemesi konvenció változása hazánkban elsősorban a „foglalkozási presztízs” - a tisztségviselés, a politikai befolyás, a kiváltságokhoz kötött nyereségszerzési monopolizált lehetöségek, a földbirtok jövedelme -, másodsorban a hagyományos fơnemesi műveltség összefüggésében a városi paloták építészetében jól kimutatható. A változás a fönemesség, illetve az arisztokrácia társadalmi osztályában a förendi méltóság (az örökös förendiházi tagság), valamint a fönemesi rang történeti-jogi és viselkedésszociológiai értelemben is vett elválását, rétegképző hatását, az építészetben pedig a foúri paloták nagyvároson belüli centralizált és izolált elhelyezését mutatja a vizsgált korszakban. 


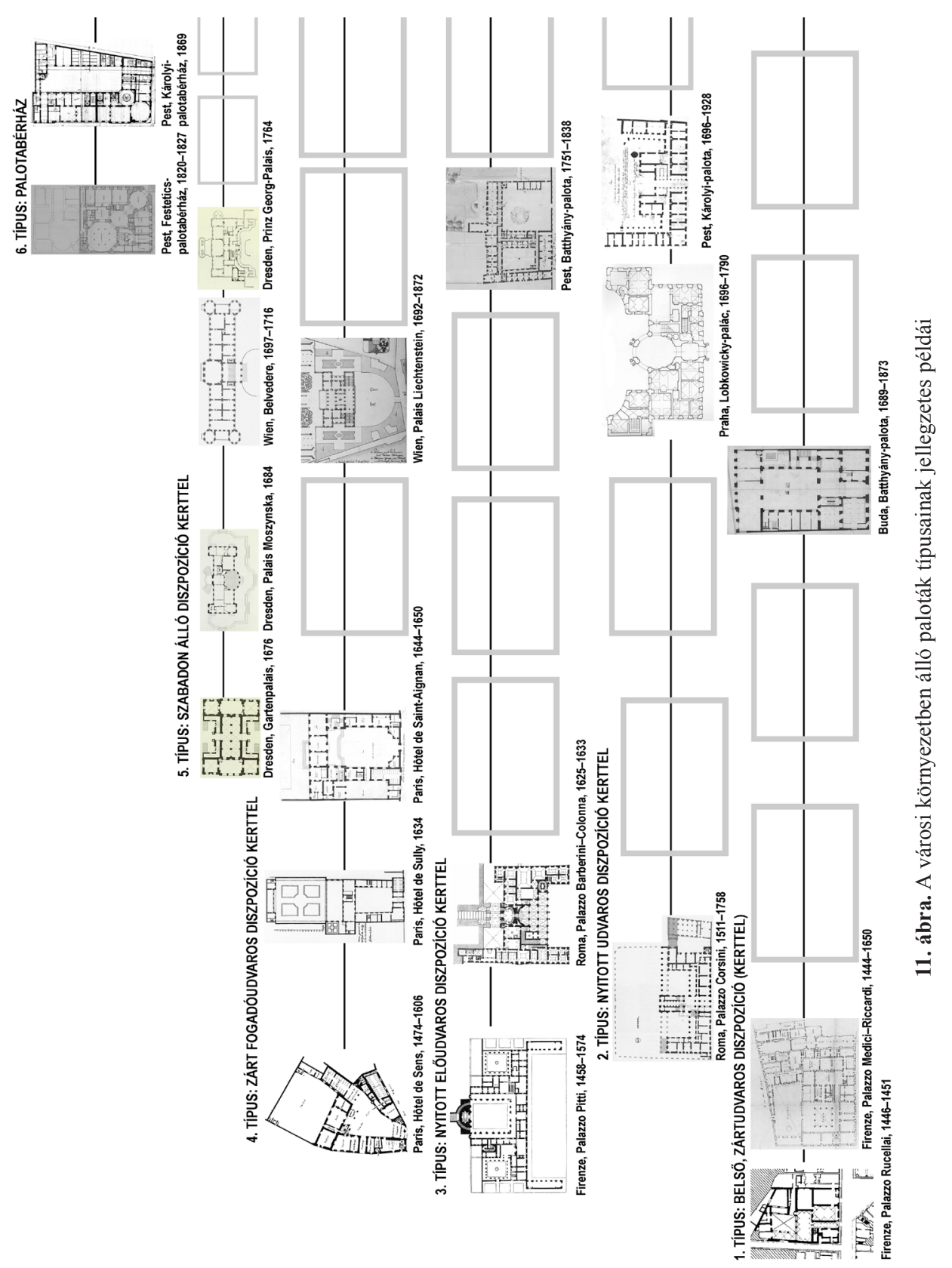




\section{IRODALOM}

Baji-Csorba 1994

Bánrévy 1952

Bende 2000

Benedek

Benzi-Montanaro 2010

Berlász 1990

Blanc-Bonnemaison 2002

Bölöny 1981

Cresti-Rendina 2007

Elias 2005

F. Dózsa 2001

G. Györffy 1991

Gosztonyi 1911

Graf 2002

Gudenus-Szentirmay 1989

Gurlitt 1903

Halmos 1995

Hatolkay 1960

Holló 1994
Baji Etelka - Csorba László: Kastélyok és mágnások. Az arisztokrácia világa a századvégi Magyarországon. HG \& Társa Kiadó, Budapest 1994.

Bánrévy György: A budai királyi palota újjáépítése III. Károly alatt. Tanulmányok Budapest múltjából. Budapest Székesfóváros, Budapest 1952. (Budapest Székesfóváros várostörténeti monográfiái 1-49.)

Bende Csaba: Paloták a Józsefvárosban. Müemléklap (2000) Márciusáprilis. 12 .

Benedek Marcellné Győri Lujza: Az empire épitészet Pesten 1800-1849. Dante Könyvkiadó, Budapest é. n.

Benzi, Fabio - Montanaro, Caroline Vincenti: Palazzi di Roma. Arsendle Editore, Roma 2010.

Berlász Jenő: Kísérletek a Könyvtár elhelyezésére a XIX. században. In: Az Országos Széchényi Könyvtár Évkönyve 1986-1990. Budapest 1990.

Blanc, Olivier - Bonnemaison, Joachim: Hôtel particuliers de Paris. Terrial-Finest SA, Paris 2002.

Bölöny József: Arisztokraták, arisztokraták... História 3 (1981) 4. 31-33. Cresti, Carlo - Rendina, Claudio: Palazzi di Roma. HF Ullmann, 2007.

Elias, Norbert: Az udvari társadalom. A királyság és az udvari arisztokrácia szociológiai jellemzőinek vizsgálata. Napvilág Kiadó, Budapest 2005.

F. Dózsa Katalin (szerk.): A budavári királyi palota évszázadai. Tanulmányok Budapest múltjából 29 (2001).

G. Györffy Katalin: Kultúra és életforma a XVIII. századi Magyarországon. Idegen utazók megfigyelései. Akadémiai Kiadó, Budapest 1991. (Müvészettörténeti füzetek 20.)

Gosztonyi Gizella: Családi és társadalmi élet III. Károly korában. Budapest, Markovits Garai Ny., 1911. (Mủvelődéstörténeti értekezések 51.)

Graf, Henriette: Die Residenz in München. Hofzeremoniell, Innenräume und Möblierung von Kurfürst Maximilian I. Bis Kaiser Karl VII. München 2002. (Bayerische Verwaltung der staatlichen Schlösser, Gärten und Seen, Forschungen zur Kunst- und Kulturgeschichte, Band VIII.)

Gudenus János - Szentirmay László: Összetört címerek. A magyar arisztokrácia sorsa és az 1945 utáni megpróbáltatások. Mozaik, Budapest 1989.

Gurlitt, Cornelius: Beschreibende Darstellung der älteren Bau- und Kunstdenkmäler des Königreichs Sachsen. Commission bei C. C. Meinhold \& Söhne, Dresden 1903.

Halmos Károly: Rangemelések a Habsburg Monarchiában. A rendi kontinuitás statisztikai elemzési lehetőségei az újnemesek és a gazdasági elit példáján. In: Á. Varga László (szerk.): Vera (nem csak) a városban. Tanulmányok a 65 éves Bácskai Vera tiszteletére. Supplementum. Csokonai K., Debrecen 1995. 445-482. (Rendi társadalom - polgári társadalom.)

Hatolkay Árpád: A Nemzeti Múzeum körül kialakult palotanegyed története. Müemlékvédelem 4 (1960) 3. 153-161.

Holló Szilvia Andrea: Budapest régi térképeken 1686-1896. Officina Nova, Budapest 1994. 
Koltai 2001

Komora 2002

Kosáry 1996

Kövér 2006

Lechner 1924

Lestyán 1940

Lörincz 1999

M. Szücs

Markó 2000

Merényi 1955

Pogány 1959

Profeti 1999

Radvánszky 1879-1896

Siklóssy 1931

Vajay 1966

Váczi 1990

Váczi 1992

Váczi 2003

Vörös 1987
[Koltai András]: Magyar udvari rendtartás. Utasitások és rendeletek 1617-1708. Osiris Kiadó, Budapest 2001. (Millenniumi magyar történelem. Források.)

Komora, Pavol: Pozsony. A vár. Bratislava 2002.

Kosáry Domokos: Müvelödés a XVIII. századi Magyarországon. Akadémiai Kiadó, Budapest 1996.

Kövér György: Magyarország társadalomtörténete a reformkortól az első világháborúig. In: Magyarország társadalomtörténete a reformkortól a második világháborúig. Szerk.: Gyáni Gábor - Kövér György. Osiris Kiadó, Budapest 2006.

Lechner Jenő: Budapest müemlékei. Budapest Székesföváros és MOB, Budapest 1924.

Lestyán Sándor: Pest-budai regélö. Officina, Budapest 1940.

Budapest in detail. Építészeti részletek. Szerk.: Lőrincz Zsuzsa. 6 Bt, Budapest 1999.

M. Szücs Ilona: Palotanegyed a Józsefvárosban. Józsefváros Önkormányzata, Budapest é. n.

Markó László: A magyar állam föméltóságai Szent Istvántól napjainkig. Magyar Könyvklub, Budapest 2000.

Merényi Ferenc: Lakóépületek és lakótelepek. In: Épületfajták Magyarországon 1890-1918. Tipológiai adatgyüjtemény. IV. kötet. Budapest 1955. (Kézirat.)

Naudin-Nicolay-Mazery 1999 Naudin, Jean-Bernard - Nicolay-Mazery, Christiane: Visite privée Hôtels particuliers de Paris. Éditions de Chêne, 1999.

Pálmány Béla: A magyarországi nemesség társadalmi tagolódása (16861815). In: Mágnások, birtokosok, címereslevelesek. Szerk.: Ódor Imre Pálmány Béla - Takács Páter. Debrecen 1997. 37-96. (Rendi társadalom - polgári társadalom 9.)

Pogány Frigyes: Budapest. Müszaki Könyvkiadó, Budapest 1959.

Profeti, Cinzia: I palazzi di Firenze. Giunti Gruppo Editoriale, Firenze 1999.

Radvánszky Béla: Magyar családélet és háztartás a XVI. és XVII. században. I-III. köt. Knoll Károly, Budapest 1879-1896.

Siklóssy László: Hogyan épült Budapest? 1870-1930. Fővárosi Közmunkák Tanácsa, Budapest 1931.

Vajay Szabolcs: Vázlat a rendi társadalom szociográfiájához. Katolikus Szemle (1966) 4. 362.

Váczi Piroska: Egy épülettípus a 19. századi Budapesten. (Bérház és palota egy épületben.) Szakdolgozat, 1990. (Kézirat.)

Váczi Piroska: Egy épülettípus a 19. századi Budapesten - palota és bérház egy épületben. Pavilon 3 (1992) 7. 66-73.

Váczi Piroska: Föúri paloták Budapesten a historizmus korában 18671914. Az arisztokrácia mozgásterének és életmódjának összefüggései egy épülettípus tükrében. Doktori értekezés, 2003. (Kézirat.)

Vörös Károly: A förendiház 1885. évi reformja. In: Társadalomtörténeti módszerek és forrástípusok. Szerk.: Á. Varga László. Salgótarján 1987. 397-405. (Rendi társadalom - polgári társadalom 1.)

\section{AZ ÁBRÁK FORRÁSA}

1-11. ábra. A szerző gyűjteményi adatbázisa és saját készítésű tablói. 


\title{
THE ARRANGEMENT OF THE HUNGARIAN NOBLE PALACES AND THEIR EUROPEAN PREFIGURATIONS WITHIN THE URBAN ENVIRONMENT IN THE $18^{\mathrm{TH}}$ AND $19^{\mathrm{TH}}$ CENTURIES
}

\begin{abstract}
Summary
The noble palace as a special type of building - due to its function - served as the residence of a family, and also represented the social position and the rank of the nobility. Since the ancient times the palace was considered as the urban residence of the wealthiest and ruling social class and as the representative symbol of its power and presence. The development of the social life in the city in modern times encouraged the nobility to stay rather in urban areas than in rural estates. In addition to participating in political and executive functions, the stay in the city was considered also as a personal representation at the events of the "season" (ball season, theater season, horse racing). The disposition (location) within the city and the architectural arrangement and design of the urban residences of the nobility, i. e. the palaces are related to the specific lifestyle of the builders. It can be interpreted and understood from a sociological point of view, because the palaces appear as the representative "architectural depiction" of a characteristic way of life in the urban area. In the $18^{\text {th }}$ and $19^{\text {th }}$ centuries the change in the way of noble life within the social class of the aristocracy indicates the separation and the stratifying effect of the nobility in historical-legal and sociological meaning. In the urban environment this is reflected either in the centralized location of the palaces around the city center or in the separate spatial location outside the city walls which was applied in Hungary as well as in the major European cities which served as role models for the Hungarian towns. As for Pressburg and Pest-Buda, the seats of ruling power - namely the royal palace and the rooms of the parliament - which were established in the $18^{\text {th }}$ and $19^{\text {th }}$ centuries, were the primary sites of noble politics and exercising power. Therefore a large number of private palaces were arranged around them. At the same time there were popular areas outside the city walls, but close to them, too, which proved to be suitable for building palaces surrounded by spacious gardens from the end of the $17^{\text {th }}$ century. In the dense urban areas there were only very limited opportunities to create gardens connecting directly to the palaces. An almost unique exception for that is the group of the terraced private noble gardens occupying the southern slopes of Prague Castle Hill. The forerunners of such spatial arrangements of the palaces can be found in the Italian cities in the $13^{\text {th }}$ and $14^{\text {th }}$ centuries. The type of these buildings emerged in Florence in the middle of the $15^{\text {th }}$ century, their first versions in Hungary were based on the buildings in Rome in the $16^{\text {th }}$ and $17^{\text {th }}$ centuries, and in Paris and Vienna in the $17^{\text {th }}$ and $18^{\text {th }}$ centuries.
\end{abstract}

Keywords: palace, disposition, noble residence, ground-plan arrangement, Baroque, Historicism 


\section{DIE ANORDNUNG DER UNGARISCHEN EDLEN PALÄSTE UND IHRER EUROPÄISCHEN VORBILDER IN STÄDTISCHER UMGEBUNG IN 18-19. JAHRHUNDERTEN}

\section{Zusammenfassung}

Der Adelspalast als besonderer Gebäudetyp diente aufgrund seiner Funktion als Wohnsitz einer Familie und repräsentierte auch die soziale Lage und den Rang des Adels. Seit der Antike galt der Palast als städtische Residenz der reichsten und herrschenden sozialen Klasse und als repräsentatives Symbol ihrer Macht und Präsenz. Die Entwicklung des gesellschaftlichen Lebens in der Stadt ermutigte den Adel in der Neuzeit, sich eher in Stadtgebieten als in ländlichen Gebieten aufzuhalten. Außer der Teilnahme an politischen und exekutiven Funktionen wurde der Aufenthalt in der Stadt auch als persönliche Vertretung bei den Veranstaltungen der „Saison“ (Ballsaison, Theatersaison, Pferderennen) angesehen. Die Disposition (Lage) innerhalb der Stadt und die architektonische Anordnung und Gestaltung der städtischen Residenzen des Adels, d.h. der Paläste beziehen sich auf den spezifischen Lebensstil der Bauherren. Es kann unter soziologischen Gesichtspunkten interpretiert und verstanden werden, daß die Paläste als repräsentative ,architektonische Darstellungen“ einer charakteristischen Lebensweise in dem großstädtischen Gefüge erscheinen. In 18. und 19. Jahrhunderten zeigte die Veränderung der Art des Hochadelslebens innerhalb der sozialen Klasse der Aristokratie eine Trennung und Schichtung des Hochadels in historisch-rechtlicher und soziologischer Bedeutung. Im städtischen Umfeld spiegelt sich dies entweder in der zentralisierten Lage der Paläste rund um die Innenstadt oder in der getrennten räumlichen Lage außerhalb der Stadtmauern wider, das wurde auch in Ungarn sowie in den europäischen Großstädten, die als Vorbilder für Ungarn dienten, angewendet. Was Preßburg und Pest-Buda betrifft, da wurden die im 18. und 19. Jahrhunderten errichteten Regierungssitze - nämlich der königliche Palast und das Parlament - die Hauptorte der edlen Politik und der Ausübung von Macht. Daher wurden eine große Anzahl privater Paläste um diese Gebäude angeordnet. Zur gleichen Zeit gab es beliebte Gebiete außerhalb der Stadtmauern, aber in ihrer Nähe, die sich ab dem Ende des 17. Jahrhunderts als geeignet erwiesen, Paläste, die von weitläufigen Gärten umgegeben waren, zu bauen. In den dichten städtischen Gebieten gab es nur sehr begrenzte Möglichkeiten, Gärten, die mit den Palästen verbunden waren, zu schaffen. Eine fast einzigartige Ausnahme bildet die Gruppe der terrassierten privaten Hochadelsgärten an den Südhängen des Prager Burgbergs. Die Vorläufer solcher räumlichen Anordnungen der Paläste konnten in den italienischen Städten in 13. und 14. Jahrhunderten gefunden werden. Der Typ der Paläste entstand in der Mitte des 15. Jahrhunderts in Florenz. Die ersten Versionen der Paläste in Ungarn basierten auf der Struktur der Gebäude in Rom aus den 16. und 17. Jahrhunderten sowie in Paris und Wien aus den 17. und 18. Jahrhunderten.

Schlüsselwörter: Palast, Disposition, Hochadelsresidenz, Grundriss, Barock, Historismus

Open Access nyilatkozat: A cikk a Creative Commons Attribution 4.0 International License (https://creativecommons.org/licenses/by/4.0) feltételei szerint publikált Open Access közlemény, melynek szellemében a cikk bármilyen médiumban szabadon felhasználható, megosztható és újraközölhetö, feltéve, hogy az eredeti szerző és a közlés helye, illetve a CC License linkje és az esetlegesen végrehajtott módosítások feltüntetésre kerülnek. (SID_1)

$\rightarrow$ Beérkezett: 2020. június 12. Elfogadva: 2020. augusztus 24.

Online First megjelenése: 2020. december 8. 